\title{
High-Temperature Metamorphic Garnets from Grenvillian Granulites of Southwestern Oaxacan Complex (Southern Mexico): Petrology, Geochemistry, Geothermobarometry, and Tectonic Implications
}

\author{
Laura Culi $^{1, *(\mathbb{D})}$, Jesús Solé ${ }^{1,2, * \mathbb{D}}$, Marc Campeny ${ }^{3}\left(\mathbb{D}\right.$ and Jeffry A. G. Oalmann ${ }^{4}(\mathbb{D}$ \\ 1 Instituto de Geología, Universidad Nacional Autónoma de México, Cd. Universitaria, \\ Ciudad de México 04510, Mexico \\ 2 Laboratorio Nacional de Geoquímica y Mineralogía, Cd. Universitaria, Ciudad de México 04510, Mexico \\ 3 Departament de Mineralogia, Museu de Ciències Naturals de Barcelona, Passeig Picasso s/n, \\ 08003 Barcelona, Spain; mcampenyc@bcn.cat \\ 4 Earth Observatory of Singapore, Nanyang Technological University, N2-01B-30, 50 Nanyang Avenue, \\ Singapore 639798, Singapore; joalmann@ntu.edu.sg \\ * Correspondence: lculi@geologia.unam.mx (L.C.); jsole@geologia.unam.mx (J.S.)
}

check for updates

Citation: Culí, L.; Solé, J.; Campeny, M.; Oalmann, J.A.G.

High-Temperature Metamorphic Garnets from Grenvillian Granulites of Southwestern Oaxacan Complex (Southern Mexico): Petrology, Geochemistry, Geothermobarometry, and Tectonic Implications. Minerals 2021, 11, 805. https://doi.org/ $10.3390 / \min 11080805$

Academic Editor: Bernhard Schulz

Received: 6 July 2021

Accepted: 21 July 2021

Published: 26 July 2021

Publisher's Note: MDPI stays neutral with regard to jurisdictional claims in published maps and institutional affiliations.

Copyright: (c) 2021 by the authors. Licensee MDPI, Basel, Switzerland. This article is an open access article distributed under the terms and conditions of the Creative Commons Attribution (CC BY) license (https:/ / creativecommons.org/licenses/by/ $4.0 /)$.

\begin{abstract}
The basement of eastern Mexico comprises Grenvillian-age granulite-facies metamorphic rocks. The Oaxacan Complex represents the largest outcrop belt of this basement in Mexico. In this work, southwestern Oaxacan Complex garnets are studied from a petrographical, geochemical, and geothermobarometrical perspective for the first time. The studied garnets display different grain sizes nucleated in a polyphase evolution. The almandine end member proportion is similar in all of the studied lithotypes. The highest pyrope concentrations are found in Qz Fsp paragenesis and ultramafic rocks and the lowest pyrope concentrations are found in amphibolite. The highest grossular and spessartine concentrations are found in the amphibolite lithotype. Southwestern Oaxacan Complex garnets from paraderivate samples are more enriched in $\mathrm{Rb}, \mathrm{Ba}, \mathrm{Pb}, \mathrm{Ni}$, and $\mathrm{Zn}$ than those from orthoderivate samples enriched in $\mathrm{Ti}$ and $\mathrm{V}$. This fact is related to the nature of the protoliths and the mineral phases that fractionate the same minor and trace elements. Garnets from para- and orthoderivate samples display $0.02-1.1 \mathrm{Eu} / \mathrm{Eu}^{*}$ anomalies. This fact indicates that almost all of the garnets formed while the plagioclase was stable, and it does not rule out the interpretation that some garnets were peritectic. The pressure obtained using a Grt-Opx-Pl-Qz geobarometer in the southwestern Oaxacan Complex is higher than the pressure obtained in the northern part of the Complex, and it is consistent with the pressure obtained in the Grenvillian-age granulites of the Novillo Gneiss from northeastern Mexico. Geothermobarometric studies reveal different P-T features at the study site, so different structural levels of the orogen are inferred.
\end{abstract}

Keywords: Grenvillian orogeny; Oaxacan Complex; garnet main end members; minor and trace elements; garnet geothermobarometry; structural levels

\section{Introduction}

Garnet (Grt) constitutes an important rock-forming mineral group in many intermediate and high-grade crustal metamorphic rocks; it is a significant mineral phase of the upper mantle lithologies, and it can be found in plutonic rocks and as a detrital component in sedimentary formations. Grt occurs in ultrabasic to acid whole-rock compositions, and its stability ranges from atmospheric pressures up to $25 \mathrm{GPa}$ and 300 to $2000{ }^{\circ} \mathrm{C}$ [1]. Aluminum-rich garnets [2] constitute one of the most important solid solution mineral groups in the Earth's crust and upper mantle [3].

The anhydrous Grt general formula may be expressed as $\left[X_{3}\right]\left[Y_{2}\right]\left(Z_{3}\right) \theta_{12}$, where $X, Y$, and $Z$ are cations, denotes octahedral coordination, ( ) denotes tetrahedral coordi- 
nation, and $\theta$ corresponds to the anion site (dodecahedral coordination). Grt exhibits an extensive solid solution; consequently, their chemical compositions are often expressed in molar proportions of the end-member components [4]. Some important Grt main end-members are almandine ( $\left.\mathrm{Alm}, \mathrm{Fe}_{3} \mathrm{Al}_{2} \mathrm{Si}_{3} \mathrm{O}_{12}\right)$, grossular $\left(\mathrm{Grs}, \mathrm{Ca}_{3} \mathrm{Al}_{2} \mathrm{Si}_{3} \mathrm{O}_{12}\right.$ ), pyrope (Prp, $\mathrm{Mg}_{3} \mathrm{Al}_{2} \mathrm{Si}_{3} \mathrm{O}_{12}$ ), spessartine (Sps, $\mathrm{Mn}_{3} \mathrm{Al}_{2} \mathrm{Si}_{3} \mathrm{O}_{12}$ ), uvarovite $\left(\mathrm{Uv}, \mathrm{Ca}_{3} \mathrm{Cr}_{2} \mathrm{Si}_{3} \mathrm{O}_{12}\right.$ ), andradite (Adr, $\mathrm{Ca}_{3} \mathrm{Fe}_{2} \mathrm{Si}_{3} \mathrm{O}_{12}$ ), majorite (Maj, $\mathrm{Mg}_{3}(\mathrm{MgSi}) \mathrm{Si}_{3} \mathrm{O}_{12}$ ), and schorlomite (Srl, $\left.\mathrm{Ca}_{3} \mathrm{Ti}_{2}\left(\mathrm{FeO}_{4}\right)\left(\mathrm{SiO}_{4}\right)\right)$ [5-7]. A vast majority of metamorphic Grts are nearly binary Alm-Prp solid solutions relatively low in the Sps and Grs components. Nevertheless, low-grade Grts are often rich in the Sps component, the composition of some granulitic (particularly mafic granulites) and mantle-derived Grts are somewhat rich in the Grs component, and Grts from eclogitic rocks can also be quite rich in the Grs component [2].

Grt is a versatile mineral group, and its study has numerous applications, e.g., the chemical composition of Grt is of particular significance in geothermobarometric studies and petrogenetic modeling $[8,9]$ as well as in many trace-element geochemical studies $[10,11]$. Rates of $\mathrm{Nd}, \mathrm{Sm}, \mathrm{Fe}, \mathrm{Mg}, \mathrm{Mn}$, and Ca diffusion in Grt and its closure temperature (Tc) are essential in studying cooling histories [12,13]. Grt is a useful provenance indicator because it has a wide compositional variation specific to certain source areas [14].

The Grenville orogeny created a Precambrian belt or belts related to one of the main episodes of crustal growth in the Earth's history [15] and led to the final assembly of the Rodinia supercontinent (1.3-1.0 Ga) [16]. The basement of eastern Mexico comprises Grenvillian-age granulite-facies metamorphic rocks [17] (Figure 1a). Grenvillian basement rocks in Mexico occur as isolated crustal units in Tamaulipas (Novillo Gneiss [18]), Hidalgo (Huiznopala Gneiss [19]), and Oaxaca (Oaxacan Complex [20], and Guichicovi Complex [21]). Late Mesoproterozoic components in Chiapas have been mostly reworked using Ordovician magmatism and metamorphism (e.g., [22]). The Oaxacan Complex (OC) represents the largest outcrop belt (ca. $6600 \mathrm{~km}^{2}$ ) of Grenvillian age, granulite-facies metamorphic rocks in Mexico. Metamorphic peak conditions in northern OC are inferred to be $836 \pm 25^{\circ} \mathrm{C}$, and $0.76 \pm 0.16 \mathrm{GPa}$ [23]; $\sim 813^{\circ} \mathrm{C}$ and $\sim 0.86 \mathrm{GPa}$ in the southern part [24]; and $825-875^{\circ} \mathrm{C}$ and $0.8-1.0 \mathrm{GPa}$ in the southwestern part [25]. In the northern OC, granulite facies metamorphism has been dated between $1.00 \pm 0.003$ and $0.98 \pm 0.003 \mathrm{Ga}$ [20] (Figure 1b).

Although there are some references regarding OC Grts, there are no previous studies of the Grts from the southwestern part of the complex. The study of southwestern OC Grts makes it possible to investigate their physical, petrographic, and geochemical features, and the P-T conditions of the region for the first time and allows the comparison of the obtained results with studies from the other parts of the complex. The most relevant ones are as follows (all mineral abbreviations according to [26]): The common presence of Grt from northern OC in the quartz-feldspathic (Qz-Fsp) paragneiss levels, in some charnockites and mafic lithologies in equilibrium with the mineral association: $\mathrm{Pl}+\mathrm{Grt}+\mathrm{Opx}+\mathrm{Hbl}$; $\mathrm{Pl}+\mathrm{Grt}+\mathrm{Cpx}+\mathrm{Qz}+\mathrm{Opx}+\mathrm{Op}$ are cited by [27]. They mention the presence of a few $\mathrm{cm}$-size Grts, which in some cases, form $\sim 60 \%$ of the whole rock (WR) in mafic and felsic gneisses from the lower crustal levels. On the other hand, the Grt composition from southern OC in the anorthositic rocks is $\mathrm{Alm}_{45-65} \operatorname{Prp}_{15-45} \mathrm{Grs}_{10-20}$. Gabbros, leucogabbros, and anorthosites contain Prp-rich Grt, which decreases when the Qz content increases. Grt from metapelite has a composition of $\mathrm{Alm}_{66} \mathrm{Prp}_{28} \mathrm{Grs}_{4} \mathrm{Sps}_{2}$ [28]. According to [29], OC Grt composition is $\mathrm{Alm}_{70-77} \operatorname{Prp}_{14-27} \mathrm{Grs}_{2-9} \mathrm{Sps}_{1-2}$. 


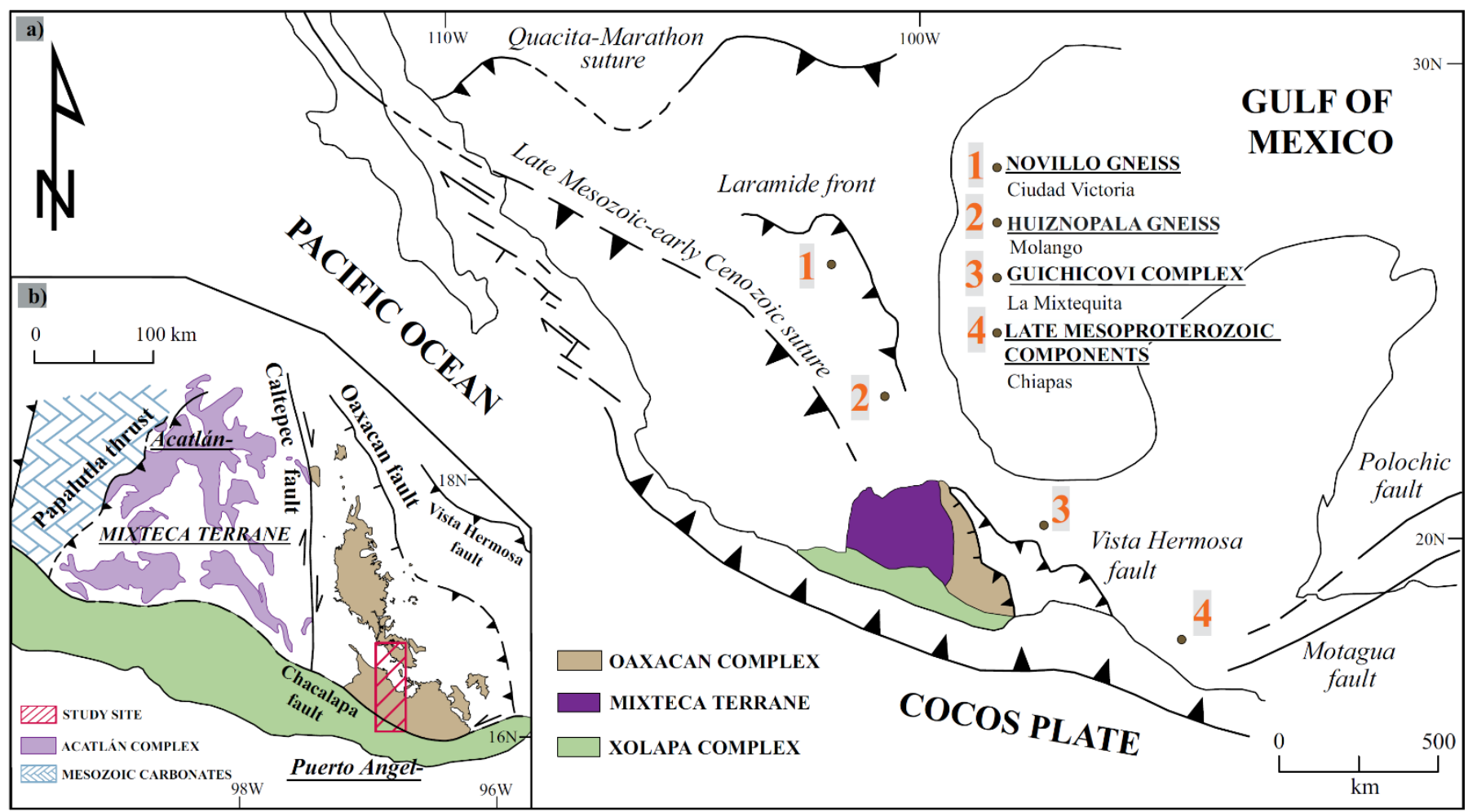

Figure 1. (a) Map of Mexico showing the main geological features. The four exposures of Grenvillian-age granulite-facies metamorphic rocks in eastern and southern Mexico are the Novillo Gneiss, Huiznopala Gneiss, Oaxacan Complex, and Guichicovi Complex. In the state of Chiapas, there are late Mesoproterozoic components that have been reworked by Ordovician magmatism and metamorphism [22]. (b) Map of southwestern Mexico showing the Xolapa, Acatlán, and Oaxacan metamorphic complexes (modified from [30]). The study area is in a red line pattern.

This work aims to characterize the southwestern OC Grts from a petrographic and geochemical point of view and infer the P-T metamorphic conditions of the southwestern OC using classical geothermobarometric techniques and crystallochemical cation assignments for Grt.

\section{Materials and Methods}

The study area is located between Ejutla de Crespo and San Baltazar Loxicha (center and southern Oaxaca State, Mexico). The OC lithological units from the study area have been divided into two main groups. The G1 is mostlycomposed of semipelitic granulites, quartz-feldspathic gneisses, and some amphibolites and calcsilicate rocks. This group is intruded by some pegmatites, anatectic marbles, orthogneisses and, in smaller or much smaller proportions migmatites, quartzites, and scarce ultramafic granulites [31] are detected. Therefore, G1 basically comprises para derivate rocks. In contrast, Group 2 (G2) is composed of intermediate and basic orthogneisses (mostly metagabbro and some belonging to the charnockitic series [32]) intruded by minor pegmatites. Therefore, G2 is basically composed of ortho derivate rocks. The general foliation trend is around N 330-N 345. In many cases, all of the studied lithotypes display Grt as a main, minor, or accessory mineral phase, whose abundance and dimensions are highly variable. Collected samples belong to G1 and G2 (Figure 2) and correspond to Qz-Fsp paragneiss, semipelitic granulite, anatectic marble, intermediate and basic orthogneiss, amphibolite, and ultramafic granulite (Table 1). 


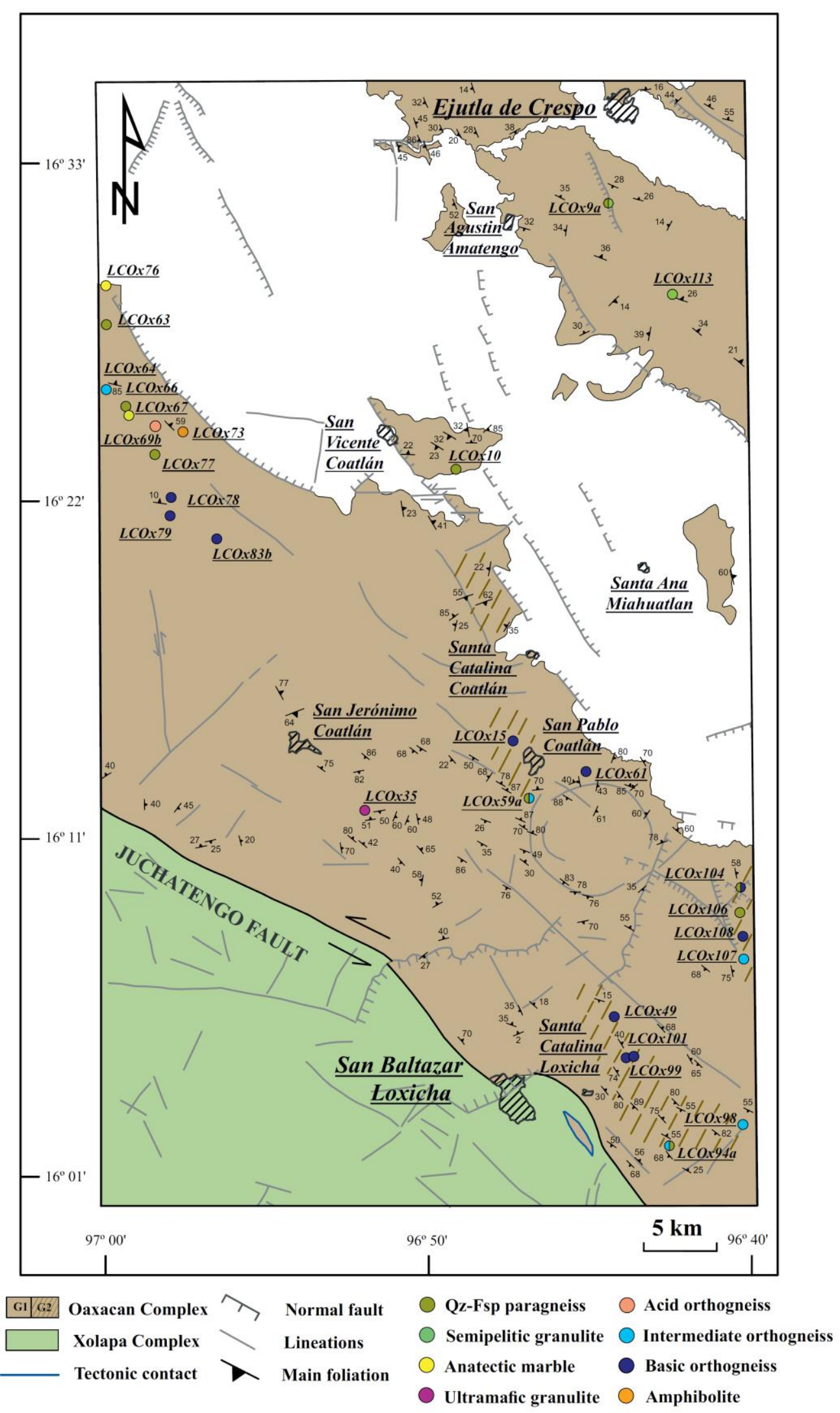

Figure 2. Simplified geological and structural map of the study area located between Ejutla de Crespo and San Baltazar Loxicha, with sample locations. Modified from 1:50,000 geological maps of Ejutla de Crespo [33] and San Baltazar Loxicha [34] and a 1:250,000 geological map of Zaachila [35]. The white colour corresponds to a Mesozoic and Cenozoic cover. 
Table 1. Collected samples with their lithotype and mineral association. LCOx26 sample is located outside the study site, northwest of the Ejutla de Crespo (Figure 2). Mineral abbreviations according to [26]; Op: opaque and Ox: oxide.

\begin{tabular}{|c|c|c|c|}
\hline Sample & \multicolumn{2}{|c|}{ Lithotype } & Mineral Association \\
\hline LCOx9a & \multirow{8}{*}{\multicolumn{2}{|c|}{ Qz-Fsp paragneiss }} & $\mathrm{Grt}+\mathrm{Pl}+\mathrm{Qz}+\mathrm{Fsp} \pm \mathrm{Rt} \pm \mathrm{Ms} \pm \mathrm{Op}$ \\
\hline LCOx10 & & & $\mathrm{Grt}+\mathrm{Pl}+\mathrm{Qz} \pm \mathrm{Fsp} \pm \mathrm{Ms} \pm \mathrm{Chl} \pm \mathrm{Ser}$ \\
\hline LCOx59a & & & $\mathrm{Grt}+\mathrm{Pl}+\mathrm{Qz}+\mathrm{Fsp}+\mathrm{Cpx}+\mathrm{Amp} \pm \mathrm{Ser} \pm \mathrm{Opx}$ \\
\hline LCOx63 & & & $\mathrm{Pl}+\mathrm{Qz}+\mathrm{Fsp}+\mathrm{Cpx}+\mathrm{Amp} \pm \mathrm{Grt} \pm \mathrm{Rt} \pm \mathrm{Ox}$ \\
\hline LCOx66 & & & $\mathrm{Grt}+\mathrm{Pl}+\mathrm{Qz}+\mathrm{Fsp} \pm \mathrm{Cpx} \pm \mathrm{Ser} \pm \mathrm{Tlc} \pm \mathrm{Op} \pm \mathrm{Ox}$ \\
\hline LCOx77 & & & $\mathrm{Grt}+\mathrm{Qz}+\mathrm{Fsp} \pm \mathrm{Pl} \pm \mathrm{Ms} \pm \mathrm{Ser} \pm \mathrm{Op} \pm \mathrm{Ox}$ \\
\hline LCOx104a & & & $\mathrm{Grt}+\mathrm{Qz}+\mathrm{Fsp} \pm \mathrm{Pl} \pm \mathrm{Ms} \pm \mathrm{Ser} \pm \mathrm{Op} \pm \mathrm{Ox}$ \\
\hline LCOx106 & & & $\mathrm{Grt}+\mathrm{Qz}+\mathrm{Fsp} \pm \mathrm{Bi} \pm \mathrm{Chl} \pm \mathrm{Ser} \pm \mathrm{Op} \pm \mathrm{Tlc}$ \\
\hline $\mathrm{LCO} 667$ & \multicolumn{2}{|c|}{ Anatectic marble } & $\mathrm{Grt}+\mathrm{Cpx}+\mathrm{Flo}+\mathrm{Scp}+\mathrm{Ol} \pm \mathrm{Qz}$ \\
\hline $\mathrm{LCOx} 26$ & \multirow{2}{*}{\multicolumn{2}{|c|}{ Semipelitic granulite }} & $\mathrm{Pl}+\mathrm{Qz}+\mathrm{Bi}+\mathrm{Cpx} \pm \mathrm{Grt} \pm \mathrm{Chl} \pm \mathrm{Amp} \pm \mathrm{Zrn} \pm \mathrm{Gr} \pm \mathrm{Op} \pm \mathrm{Ox}$ \\
\hline LCOx113 & & & $\mathrm{Pl}+\mathrm{Qz}+\mathrm{Bi}+\mathrm{Ms} \pm \mathrm{Grt} \pm \mathrm{Fsp} \pm \mathrm{Cpx} \pm \mathrm{Zrn} \pm \mathrm{Ser} \pm \mathrm{Op} \pm \mathrm{Ox} \pm \mathrm{Ap}$ \\
\hline LCOx73 & \multicolumn{2}{|c|}{ Amphibolite } & $\mathrm{Pl}+\mathrm{Amp} \pm \mathrm{Grt} \pm \mathrm{Chl}$ \\
\hline LCOx35 & \multicolumn{2}{|c|}{ Ultramafic granulite } & $\mathrm{Grt}+\mathrm{Opx}+\mathrm{Amp} \pm \mathrm{Cpx} \pm \mathrm{Mag} \pm \mathrm{Hc}$ \\
\hline LCOx15 & \multirow{16}{*}{ Orthogneiss } & $\mathrm{B}^{1}$ & $\mathrm{Grt}+\mathrm{Pl}+\mathrm{Cpx}+\mathrm{Opx}+\mathrm{Amp} \pm \mathrm{Fsp} \pm \mathrm{Op}$ \\
\hline $\mathrm{LCO} \times 49$ & & $\mathrm{~B}^{1}$ & $\mathrm{Grt}+\mathrm{Pl}+\mathrm{Cpx}+\mathrm{Opx}+\mathrm{Amp} \pm \mathrm{Fsp} \pm \mathrm{Op}$ \\
\hline LCOx59b & & $\mathrm{I}^{3}$ & $\mathrm{Grt}+\mathrm{Pl}+\mathrm{Qz}+\mathrm{Fsp}+\mathrm{Cpx}+\mathrm{Amp} \pm \mathrm{Ser} \pm \mathrm{Op}$ \\
\hline LCOx61 & & $\mathrm{B}^{1}$ & $\mathrm{Grt}+\mathrm{Pl}+\mathrm{Amp}+\mathrm{Cpx} \pm \mathrm{Qz} \pm \mathrm{Opx} \pm \mathrm{Ap} \pm \mathrm{Zrn} \pm \mathrm{Op}$ \\
\hline LCOx64 & & $\mathrm{I}^{3}$ & $\mathrm{Grt}+\mathrm{Qz}+\mathrm{Fsp}+\mathrm{Cpx} \pm \mathrm{Zrn} \pm \mathrm{Op} \pm \mathrm{Ap}$ \\
\hline LCOx69b & & $\mathrm{A}^{2}$ & $\mathrm{Grt}+\mathrm{Pl}+\mathrm{Qz}+\mathrm{Fsp} \pm \mathrm{Cpx} \pm \mathrm{Opp} \pm \mathrm{Zrn} \pm \mathrm{Op}$ \\
\hline $\mathrm{LCOx78}$ & & $\mathrm{B}^{1}$ & $\mathrm{Grt}+\mathrm{Pl}+\mathrm{Opx}+\mathrm{Cpx}+\mathrm{Amp} \pm \mathrm{Op}$ \\
\hline LCOx79 & & $\mathrm{B}^{1}$ & $\mathrm{Grt}+\mathrm{Pl}+\mathrm{Cpx}+\mathrm{Amp}+\mathrm{Bi} \pm \mathrm{Qz} \pm \mathrm{Opx} \pm \mathrm{Zrn} \pm \mathrm{Ox} \pm \mathrm{Op}$ \\
\hline LCOx83b & & $\mathrm{B}^{1}$ & $\mathrm{Pl}+\mathrm{Cpx}+\mathrm{Grt} \pm \mathrm{Opx} \pm \mathrm{Amp} \pm \mathrm{Bi} \pm \mathrm{Op}$ \\
\hline LCOx94a & & $\mathrm{I}^{3}$ & $\mathrm{Grt}+\mathrm{Pl}+\mathrm{Opx}+\mathrm{Cpx}+\mathrm{Bi} \pm \mathrm{Fsp} \pm \mathrm{Op}$ \\
\hline LCOx98 & & $\mathrm{I}^{3}$ & $\mathrm{Grt}+\mathrm{Pl}+\mathrm{Qz}+\mathrm{Cpx}+\mathrm{Bi} \pm \mathrm{Fsp} \pm \mathrm{Ser} \pm \mathrm{Chl} \pm \mathrm{Zrn} \pm \mathrm{Op} \pm \mathrm{Ox}$ \\
\hline LCOx99 & & $\mathrm{I}^{3}$ & $\mathrm{Grt}+\mathrm{Pl}+\mathrm{Qz}+\mathrm{Cpx}+\mathrm{Opx} \pm \mathrm{Bi} \pm \mathrm{Ser} \pm \mathrm{Rt} \pm \mathrm{Op}$ \\
\hline LCOx101 & & $\mathrm{B}^{1}$ & $\mathrm{Grt}+\mathrm{Pl}+\mathrm{Qz}+\mathrm{Fsp}+\mathrm{Cpx}+\mathrm{Amp}+\mathrm{Bi} \pm \mathrm{Fsp} \pm$ Ser \pm Op \\
\hline LCOx104b & & $\mathrm{B}^{1}$ & $\mathrm{Grt}+\mathrm{Pl}+\mathrm{Qz}+\mathrm{Fsp}+\mathrm{Cpx}+\mathrm{Opx} \pm \mathrm{Bi} \pm \mathrm{Ser} \pm \mathrm{Op} \pm \mathrm{Chl}$ \\
\hline LCOx107 & & $\mathrm{I}^{3}$ & $\mathrm{Grt}+\mathrm{Pl}+\mathrm{Cpx}+\mathrm{Opx} \pm \mathrm{Qz} \pm \mathrm{Ser} \pm \mathrm{Op} \pm \mathrm{Chl} \pm \mathrm{Ap}$ \\
\hline LCOx108 & & $\mathrm{B}^{1}$ & $\mathrm{Pl}+\mathrm{Opx}+\mathrm{Cpx}+\mathrm{Amp} \pm \mathrm{Grt}$ \\
\hline
\end{tabular}

${ }^{1}$ B: Basic, ${ }^{2}$ A: Acid, and ${ }^{3}$ I: Intermediate.

The Qz-Fsp paragneiss is the only lithotype developing Grt ocelli up to $2 \mathrm{~cm}$ (augen gneiss textures) (Figure 3a). In some outcrops from the central and southwestern part of the study site, Qz-Fsp paragneiss and orthogneiss lithotypes hold up to $60 \% \mathrm{Grt}$, constituting garnetites (Figure $3 b, c)$. In other cases, there are abundant centimetric to millimetric Grt levels (Figure 3d), which locally have a large size range. In some outcrops from a migmatite lithotype, Grt porphyroblasts have dimensions from millimetric to centimetric size (Figure 3e). Elsewhere, quartzite lithotypes display millimetric- to centimetric-sized Grt porphyroblasts (Figure 3f). 

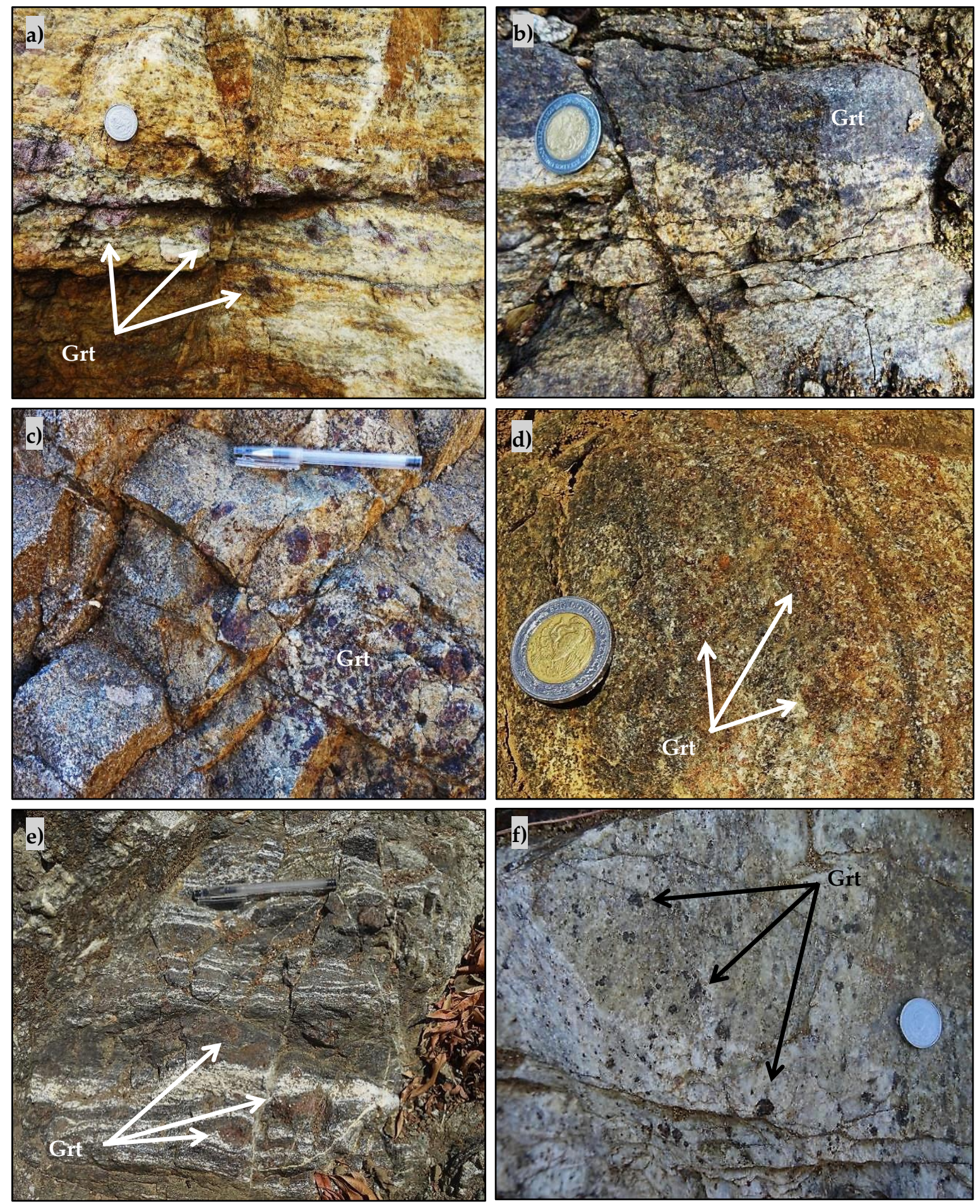

Figure 3. (a) Grt outcrop with augen gneiss textures from Qz-Fsp paragneiss. (b) Outcrop of centimetric to millimetric Grt size levels, which constitute a garnetite from Qz-Fsp paragneiss. (c) Outcrop of orthogneiss lithotype that holds up to 60\% Grt constituting a garnetite. (d) Outcrop of centimetric to millimetric size Grt from basic orthogneiss. (e) Outcrop with centimetric Grt porphyroblasts from migmatite. (f) Outcrop with millimetric and centimetric Grt porphyroblasts from quartzite. The size of the scale markers: pen $=13.5 \mathrm{~cm}$ and coin $2.5 \mathrm{~cm}$.

Petrographic studies were conducted on a thin section using optical microscopy at Laboratorio Nacional de Geoquímica y Mineralogía from the Universidad Nacional Autónoma de México (UNAM). 
Polished thin sections and individual crystals mounted on polished molds using EpoFix resin were used to study Grt geochemistry. For Grt separation, the samples were crushed using a steel jaw crusher, processed further in a steel mortar, and split into grainsized fractions by sieving. Finally, Grt crystal concentrates were manually handpicked using a stereomicroscope to ensure that they did not contain inclusions of other minerals.

Grt, Opx, Cpx, and Pl were analyzed with wavelength-dispersive spectrometry (EPMA-WDS) at the Centres Científics i Tecnològics de la Universitat de Barcelona (CCiTUB). Analyses were performed on a JEOL JXA-8230 electron microprobe with five wavelength-dispersive spectrometers (WDS) and a silicon-drift detector EDS. For spot analyses, the electron column was set to an accelerating voltage of $15 \mathrm{kV}$, a beam current of $10 \mathrm{nA}$, standard counting times of $10 \mathrm{~s}$, and a focused beam to achieve the best lateral resolution. In addition, background positions were carefully adjusted. The analytical standards that were used were hematite $(\mathrm{Fe}, \mathrm{LIF}, \mathrm{K} \alpha)$; rutile $(\mathrm{Ti}, \mathrm{PET}, \mathrm{K} \alpha)$; periclase $(\mathrm{Mg}$, TAP; $\mathrm{K} \alpha$ ); rhodonite (Mn, LIF, $\mathrm{K} \alpha) ; \mathrm{Al}_{2} \mathrm{O}_{3}(\mathrm{Al}, \mathrm{TAP}, \mathrm{K} \alpha) ; \mathrm{Cr}_{2} \mathrm{O}_{3}(\mathrm{Cr}, \mathrm{PET}, \mathrm{K} \alpha)$; diopside (Si, TAP, $\mathrm{K} \alpha)$; wollastonite $(\mathrm{Ca}, \mathrm{PET}, \mathrm{K} \alpha)$; orthoclase $(\mathrm{K}, \mathrm{PET}, \mathrm{K} \alpha)$; barite $(\mathrm{Ba}, \mathrm{PET}, \mathrm{K} \alpha)$; and albite $(\mathrm{Na}, \mathrm{TAP}, \mathrm{K} \alpha)$.

Grt trace element concentrations were measured using a Photon Machines Analyte G2 193 nm ArF excimer laser equipped with a HelEx two-volume sample cell coupled to a Thermo iCAP Q ICP-MS at the LA-ICP-MS Laboratory of the Earth Observatory of Singapore, Nanyang Technological University, Singapore. Using a square spot size of $40 \mu \mathrm{m} \times 40 \mu \mathrm{m}$, a $30 \mathrm{~s}$ ablation was carried out at a $10 \mathrm{~Hz}$ pulse repetition rate with a fluence of $3.5 \mathrm{~J} / \mathrm{cm}^{2}$. The ablated material was transported in He with a total flow rate of $11 / \mathrm{min}$ and mixed with approximately $0.7 \mathrm{~L} / \mathrm{min}$ Ar that was approximately $10 \mathrm{~cm}$ upstream from the torch. The plasma was sustained at $1550 \mathrm{~W}$, and the system was tuned to maximize sensitivity while keeping $\mathrm{ThO} / \mathrm{Th}<1 \%$. The Trace_Elements_IS data reduction scheme [36] of Iolite v 3. 6 [37] was used to reduce the data, using standard-sample bracketing with USGS basaltic glass GSD-1G as the primary calibration standard plus internal standardization, with Si concentrations determined by EPMA. Reproducibility of the secondary reference materials (BCR-2G and $\mathrm{BHVO}-2 \mathrm{G}$ ) ranged from $2-7 \%$ relative standard deviation for elements with concentrations $>0.1 \mathrm{ppm}$, and the measured concentrations of these reference materials were within $10 \%$ of the Georem preferred values [38].

\section{Results}

Depending on the accessibility of the terrain, the degree of alteration and the minerals visible on a hand sample, different samples with no alteration, and interesting mineral association were collected. A total of 29 Grt samples belonging to high-grade granulitic metamorphic rocks were selected for petrographic studies, 24 for major element studies, 13 for minor and trace element geochemical studies, and 10 for classical geothermobarometric studies.

\subsection{Garnet Petrography}

From a textural point of view, the studied Grts displayed two main features: (1) Resorbed borders (Figure 4a), indicating that its nucleation occurred during prograde metamorphism (pre- or syn- metamorphic peak) [39]. Mineral resorbed borders often exhibit irregular morphologies, such as embayments (Figure 4b), which often contrast with the original sharp crystal growth faces [40]. In some cases, resorbed Grts constitute aggregates (Figure 4c,d) or display interstitial tendencies (Figure 4e). Resorbed Grts are blastopoikilitic of Qz, Pl, Amp, Opx, Ap (Figure 4f-h), Bi, Fe-Ti oxides, and Mag (Figure S1a,b). (2) Grts with idiomorphic borders are always smaller than resorbed Grts and never display blastopoikilitic texture (Figure 4i and Figure S1c); therefore, their nucleation must have occurred in retrograde metamorphism (syn- or post-metamorphic peak). 



Figure 4. Cont. 

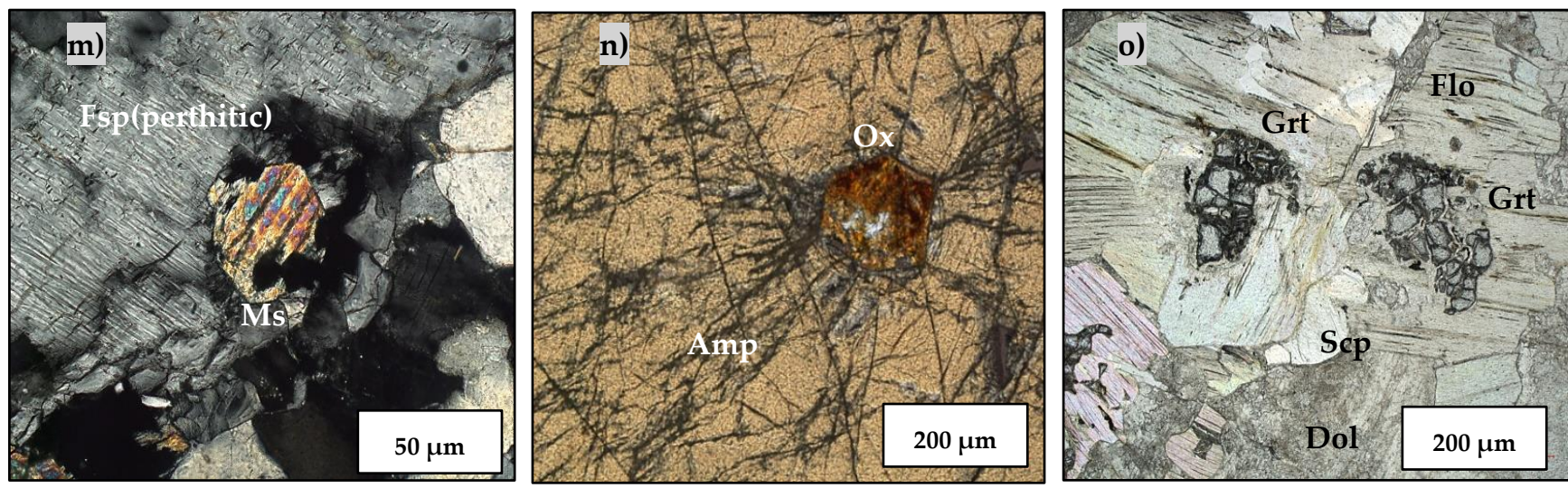

Figure 4. Optical microscope images of southwestern Oaxacan Complex garnets: (a) Suballotriomorphic Grt in crossed nicols from Qz-Fsp paragneiss (LCOx77); (b) Suballotriomorphic Grt blastopoikilitic of Qz Grt aggregate in crossed nicols from basic orthogneiss (LCOx83b); (c) Suballotriomorphic Grt aggregates in crossed nicols from basic orthogneiss (LCOx61); (d) Suballotriomorphic Grt with interstitial tendency in crossed nicols from intermediate orthogneiss (LCOx98); (e) Suballotriomorphic Grt blastopoikilitic of Qz, Pl, Amp, and Ap in crossed nicols from intermediate orthogneiss (LCOx64); (f) Suballotriomorphic Grt blastopoikilitic of Qz in crossed nicols from Qz-Fsp paragneiss (LCOx10); (g) Suballotriomorphic Grt blastopoikilitic of Opx, Pl, and Amp in crossed nicols from intermediate orthogneiss (LCOx59b); (h) Subidiomorphic Grt with partial Chl rims in plane polarized light from semipelitic granulite (LCOx26); (i) Boudins of Grt, $\mathrm{Pl}$, and Qz in plane polarized light from Qz-Fsp paragneiss (LCOx9a); (j) Incipient Boudins of Grt surrounded by Ser, Pl, and Qz in crossed nicols from basic orthogneiss (LCOx49); (k) Amp formed at the expense of Grt in crossed nicols from intermediate orthogneiss (LCOx59b); (1) Bi formed at the expense of Grt in plane polarized light from basic orthogneiss (LCOx101); (m) Grt mold filled by Ms in crossed nicols from Qz-Fsp paragneiss (LCOx83a); (n) Grt mold filled by oxides in plane polarized light from amphibolite (LCOx73); (o) Consumed Grt rims in plane polarized light from anatectic marble (LCOx76).

On the other hand, the studied Grts do not display any deformation, and boudin textures have only been observed in a few samples (Figure $4 \mathrm{j}, \mathrm{k}$ ). In some cases, it seems that Amp (Figure 4l) and Bi (Figure 4m and Figure S1d) are formed at the expense of Grts, suggesting that $\mathrm{Bi}$ and Amp are high-medium metamorphic retrograde hydrated phases, e.g., following $\mathrm{Hbl}+\mathrm{Qz}=\mathrm{Grt}+\mathrm{Opx}+\mathrm{Cpx}+\mathrm{H}_{2} \mathrm{O}$ [41] and Alm + Flo $=\mathrm{Ann}+\operatorname{Prp}$ [42] reactions. Some Grts display Ms (Figure $4 \mathrm{~m}$ ), oxide (Figure $4 \mathrm{n}$ ) filled molds, or crystal faces with reaction texture (Figure 4o) or inclusion trails (Figure S1e). Finally, Qz and Grt symplectite had only been detected in one sample from a Qz-Fps paragneiss lithotype (Figure S1f).

\subsection{Garnet Geochemistry}

\subsubsection{Major Elements}

Southwestern OC Grts mainly fall in the granulite field when they are plotted in ternary diagrams based on the molar ratio of the Grt main end members Alm, Prp, Grs, and Sps (Figure 5, modified from [43]). The first Grt main end member from the Qz-Fsp paragneiss lithotype is Alm (except in Grt from LCOx66, which is Grs, and Grt from LCOx77, which is Prp), and the last is Sps. The proportions of Grs and Prp from this lithotype are the most assorted. Thr LCOx9a Grt sample has the lowest Grs content and the highest Prp content, and LCOx77 has the highest Grs and the lowest Prp content. Therefore, the increase in one component implies a decrease in the other (Figure 5a). The general Grt main end-member composition of the Qz-Fsp paragneiss lithotype is $\mathrm{Alm}_{41-73} \operatorname{Prp}_{2-42} \mathrm{Grs}_{3-20} \mathrm{Sps}_{1-8}$. One Grt from a semipelitic granulite lithotype is available (LCOx113, Figure 5a), the composition of which is $\mathrm{Alm}_{58-63} \operatorname{Prp}_{15-20} \mathrm{Grs}_{19-22} \mathrm{Sps}_{2-3}$. 


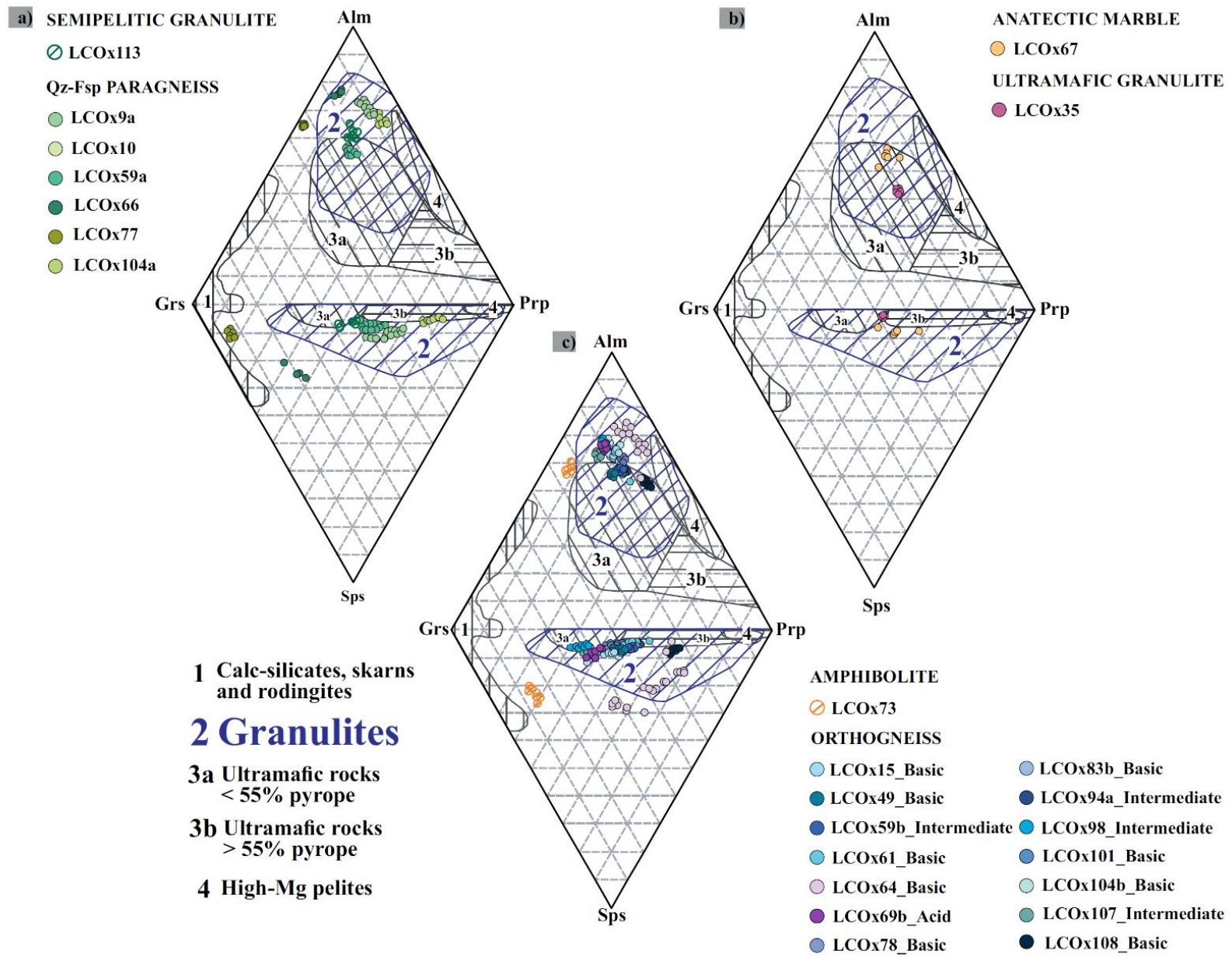

Figure 5. Ternary plots based on the molar ratio of Grt main end members Alm (almandine), Prp (pyrope), Grs (grossular), and Sps (spessartine): (a) Ternary plot of Grts from semipelitic and Qz-Fsp paragneiss lithotypes; (b) Ternary plot of Grts from anatectic marble and ultramafic granulite lithotypes; (c) Ternary plot of Grts from basic, intermediate, and acid orthogneiss lithotypes. Modified from [43].

The first Grt main end member from the orthogneiss lithotype is Alm, the second is Prp, and the third is Grs. However, the Grt from the LCOx15, LCOx69b, and LCOx83b samples displays similar proportions of Grs and Prp. On the other hand, Grt from the LCOx78, LCOx98, LCOx101, and LCOx107 samples displays Grs as the second main end member (Figure $5 b$ ). The general Grt composition of the orthogneiss lithotype is $\mathrm{Alm}_{48-66} \operatorname{Prp}_{13-33} \mathrm{Grs}_{9-20} \mathrm{Sps}_{2-11}$. One Grt from the amphibolite lithotype sample is available (LCOx73, Figure 5b), the composition of which is Alm $49-51 \operatorname{Prp}_{6-7} \mathrm{Grs}_{30-34} \mathrm{Sps}_{10-13}$ and is the studied Grt with the highest Ca content.

One Grt from the ultramafic granulite lithotype is available (LCOx35, Figure 5c); its composition is $\mathrm{Alm}_{43-49} \operatorname{Prp}_{31-37} \mathrm{Grs}_{18-19} \mathrm{Sps}_{2}$, and it is the Grt sample with the highest $\mathrm{Mg}$ content. Last, one Grt from the anatectic marble lithotype (LCOx67, Figure 5c) has a composition of $\mathrm{Alm}_{64} \operatorname{Prp}_{13-16} \mathrm{Grs}_{18-19} \mathrm{Sps}_{3-4}$. Microprobe analyses of the studied Grts are shown in Table S1.

Studied Grts display low to nonexistent zoning in major element profiles (Figure S2). The lack of zoning is typical of high T (HT) metamorphic rocks because the diffusion of the major elements in Grt is effective and implies such textural features. Therefore, no significant compositional variations are observed.

Major Grt oxides were used to compute a Principal Component Analysis (PCA) diagram, which is plotted in Figure 6. Both oxides and Grt end members have been plotted to show the components that create the sample discrimination. Observe that the Grt from paragneisses and the orthogneisses can be distinguished by tracing some of the lines in the 
diagram, as is also the case for the Grt from pyroxenite and amphibolite samples that are plotted in separate regions. The Alm and andradite components (And, $\left.\left\{\mathrm{Ca}_{3}\right\}\left[\mathrm{Fe}_{2}\right]\left(\mathrm{Si}_{3}\right) \mathrm{O}_{12}\right)$ were calculated by the total amount of $\mathrm{FeO}$ in each formula, so they are not dependent on the $\mathrm{Fe}^{3+}$ method calculation. The studied Grts display Alm, Prp, Grs, and Sps main end member components but also display andradite (And, $\left.\left\{\mathrm{Ca}_{3}\right\}\left[\mathrm{Fe}_{2}\right]\left(\mathrm{Si}_{3}\right) \mathrm{O}_{12}\right)$ and uvarovite $\left(\mathrm{Uv},\left\{\mathrm{Ca}_{3}\right\}\left[\mathrm{Cr}_{2}\right]\left(\mathrm{Si}_{3}\right) \mathrm{O}_{12}\right)$ in the PCA diagram.

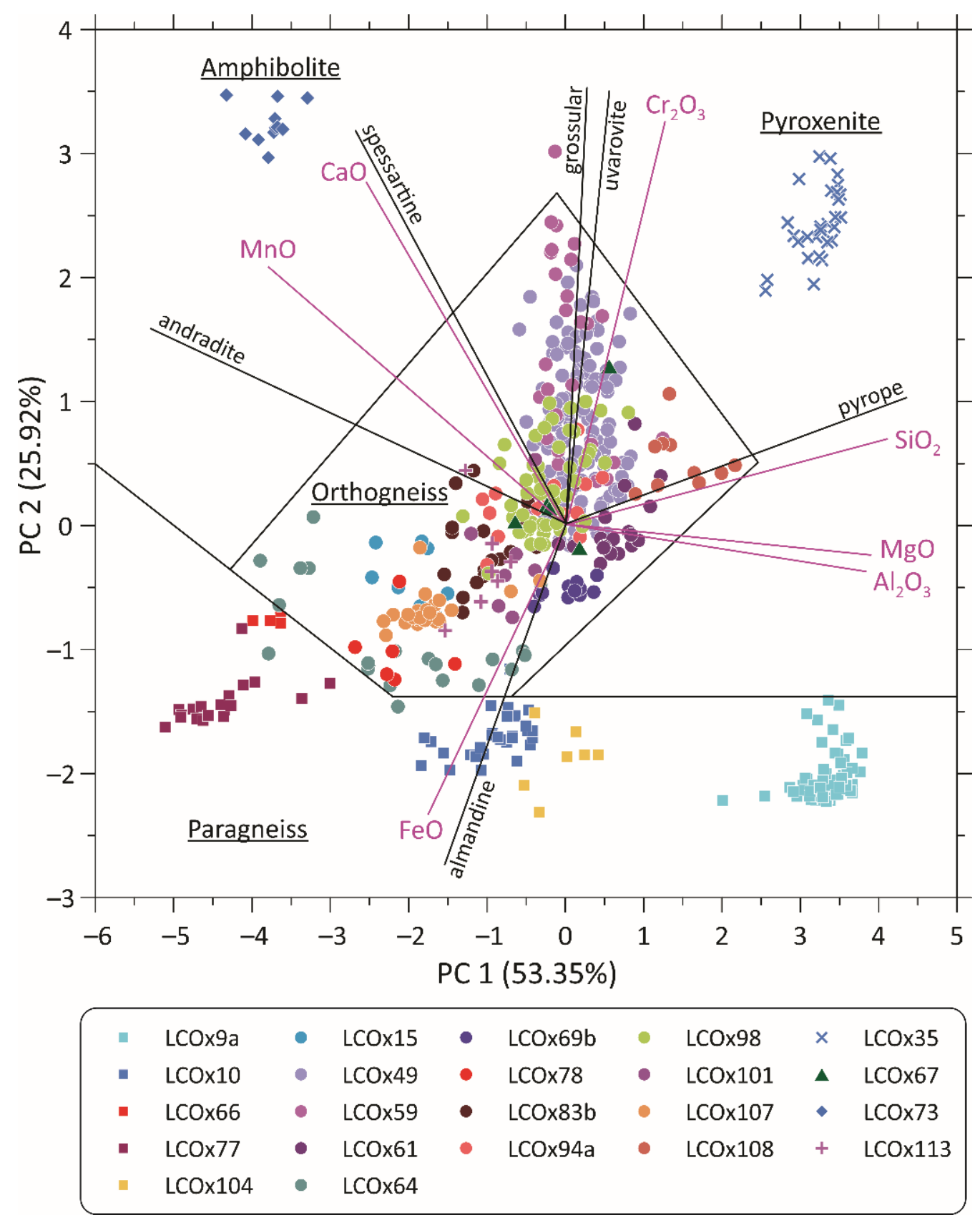

Figure 6. Principal Component Analysis (PCA) of Grt major oxides. Principal Components 1 and 2 are shown with their explained percentage of variance.

The cation preferences $\left(\mathrm{H}, \mathrm{Na}, \mathrm{Mg}, \mathrm{Al}, \mathrm{Si}, \mathrm{Ca}, \mathrm{Sc}, \mathrm{Ti}, \mathrm{V}, \mathrm{Cr}, \mathrm{Mn}^{2+}, \mathrm{Mn}^{3+}, \mathrm{Fe}^{2+}, \mathrm{Fe}^{3+}\right.$, $\mathrm{Y}, \mathrm{Zr}$, and $\mathrm{Sn}$ ) for the tetrahedral, dodecahedral, and octahedral sites have been reported in the literature from the results of many Grt crystal structure refinements and spectroscopic investigations [4]. The Excel spreadsheet from [4] has been used to conduct a deep analysis of the minor and main end member components of Grt and Grt chemistry. Grts 
from all of the studied lithotypes have And, goldmanite $\left(\left\{\mathrm{Ca}_{3}\right\}\left[\mathrm{V}_{2}\right]\left(\mathrm{Si}_{3}\right) \mathrm{O}_{12}\right)$, kimzeyite ( $\left\{\mathrm{Ca}_{3}\right\}\left[\mathrm{Zr}_{2}\right]\left(\mathrm{SiAl}_{2}\right) \mathrm{O}_{12}$, Sc garnet $\left(\left\{\mathrm{Ca}_{3}\right\}\left[\mathrm{Sc}_{2}\right]\left(\mathrm{Si}_{3}\right) \mathrm{O}_{12}\right)$, schorlomite- $\mathrm{Al}\left(\left\{\mathrm{Ca}_{3}\right\}\left[\mathrm{Ti}_{2}\right]\left(\mathrm{SiAl}_{2}\right) \mathrm{O}_{12}\right)$, $\mathrm{Uv}$, and yttrogarnet $\left(\left\{\mathrm{Y}_{3}\right\}\left[\mathrm{Al}_{2}\right]\left(\mathrm{Al}_{3}\right) \mathrm{O}_{12}\right)$ as minor main end members (Table S2). The tetrahedral ( $\mathrm{Si}$ and $\mathrm{Al})$, dodecahedral $\left(\mathrm{Y}, \mathrm{Fe}^{2+}, \mathrm{Mn}^{2+}, \mathrm{Mg}\right.$, $\left.\mathrm{Ca}, \mathrm{Na}\right)$, and octahedral (Ti, $\mathrm{Zr}, \mathrm{Sn}, \mathrm{Al}$, $\mathrm{Sc}, \mathrm{Cr}, \mathrm{V}, \mathrm{Fe}^{2+}$ and $\mathrm{Fe}^{3+}$ ) site assignments from OC Grts are shown in Table S3. It should be noted that it is possible to calculate the octahedral assignments, but only for those Grts where trace element analyses are available (see next section). Grts from anatectic marble and amphibolite have not been considered because only one Grt sample is available from these lithotypes. Grt cation assignments, together with other Grt features, are evaluated in the discussion section.

\subsubsection{Minor and Trace Elements}

The minor and trace element patterns normalized to the chondritic reservoir (CHUR, [44]) from studied Grts are shown in Figure 7. Paraderivate Grt samples (green patterns) are more enriched in $\mathrm{Sc}, \mathrm{Ni}, \mathrm{Zn}, \mathrm{Rb}, \mathrm{Ba}, \mathrm{Cs}$, and $\mathrm{Pb}$ than orthoderivate Grt samples (blue patterns), which are more enriched in Ti and V. Broadly, Grts from paraderivate samples have higher REE concentrations than those of orthoderivate samples. All Grts are characterized by a depletion in LREE $\left(\mathrm{La}_{\mathrm{N}} / \mathrm{Gd}_{\mathrm{N}} \approx 4.0 \times 10^{-5}-0.2\right.$; mostly $\left.0.001-0.002\right)$ and slightly positively sloping to flat HREE patterns $\left(\mathrm{Gd}_{\mathrm{N}} / \mathrm{Lu}_{\mathrm{N}} \approx 0.1-2.2\right)$. Grts from orthoderivate samples display negative to slightly positive $\mathrm{Eu}$ anomalies $\left.\left(\mathrm{Eu} / \mathrm{Eu}^{*}=\mathrm{Eu}_{\mathrm{N}} /\left(\mathrm{Sm}_{\mathrm{N}} \times \mathrm{Gd}_{\mathrm{N}}\right)^{0.5}\right) \approx 0.2-1.1\right)$ and both negative and positive $\mathrm{Ce}$ anomalies $\left.\left(\mathrm{Ce} / \mathrm{Ce}^{*}=\mathrm{Ce}_{\mathrm{N}} /\left(\mathrm{La}_{\mathrm{N}} \times \mathrm{Pr}_{\mathrm{N}}\right)^{0.5}\right) \approx 0.7-1.5\right)$. Grts from paraderivate samples display strongly negative $\mathrm{Eu}$ anomalies $\left(\mathrm{Eu} / \mathrm{Eu}^{*} \approx 0.02-0.2\right.$, below 1$)$ and slightly negative to weakly positive $\mathrm{Ce}$ anomalies $\left(\mathrm{Ce} / \mathrm{Ce}^{*} \approx 0.8-1.9\right)$, and flat to negatively sloping trends in the middle (MREE) to heavy REEs $\left(\mathrm{Gd}_{\mathrm{N}} / \mathrm{Lu}_{\mathrm{N}}\right) \approx 0.1-2.2$ (Table S4).

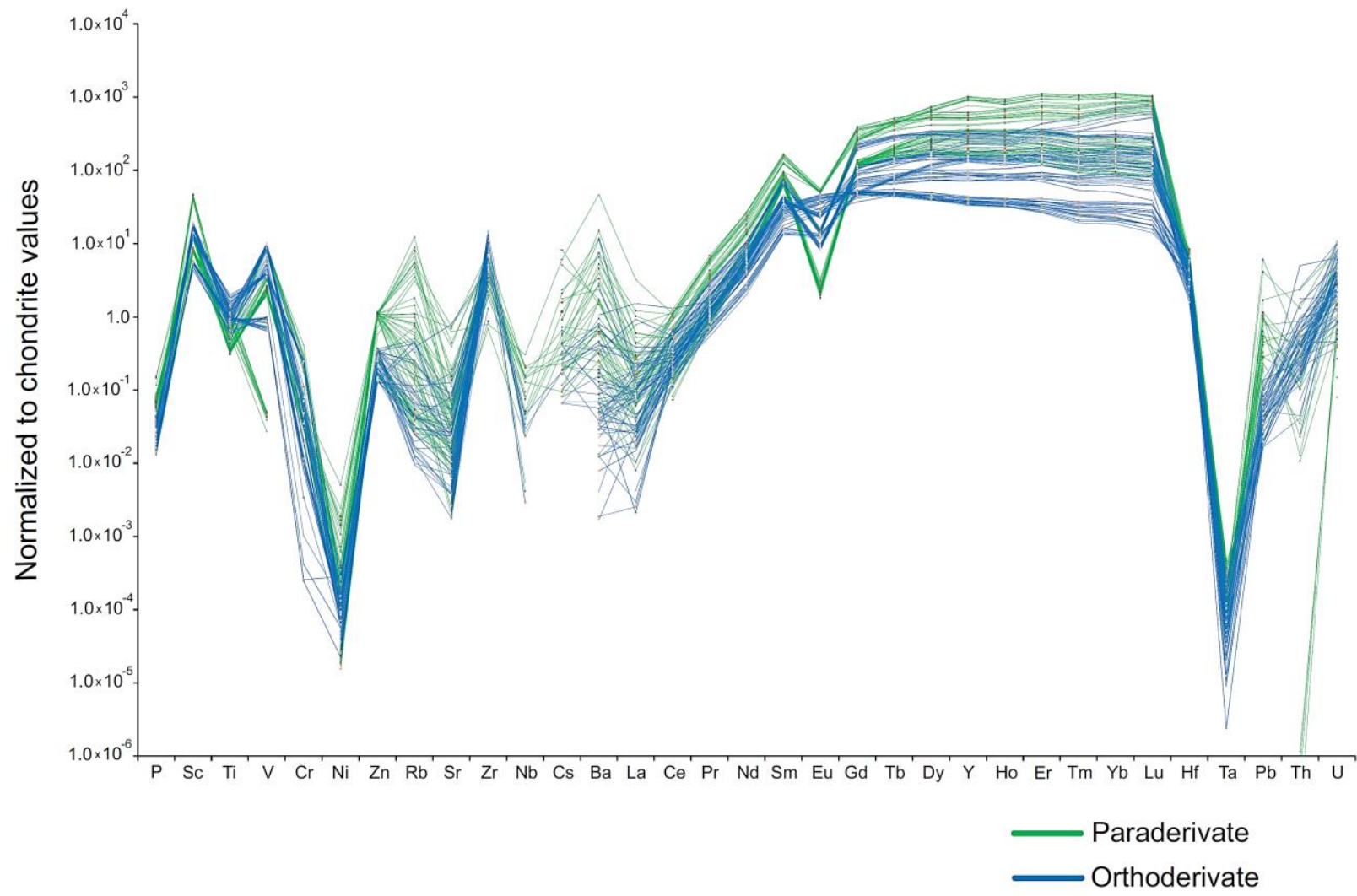

Figure 7. Minor and trace element patterns normalized to the chondritic reservoir (CHUR, [44]) of southwestern Oaxacan Complex Grts. The green pattern represents Grts from paraderivate samples and, the blue pattern represents Grts from orthoderivate samples. 
Concerning the LREE, most of the studied Grts display core La, Ce, and Pr profiles located between those of their rims, i.e., the concentration of these elements at the rims is higher or lower than the core. However, the Grts from the LCOx78 and LCOx83b samples display lower La concentrations in their cores than their rims and, the Grts from LCOx49 has lower $\mathrm{Ce}$ and Pr concentrations in their core than rims. Concerning the MREE, most of the Grt core samples display Nd, Sm, Eu, and Gd profiles above or between those of the rims. All of the Grt cores display Eu negative anomalies, except Grts from LCOx78 and LCOx79 samples, which do not display an Eu anomaly (Figure S3). HREE Grt core profiles from LCOx49 and LCOx98 samples are more negatively sloping than the HREE patterns of the Grt rims. Last, most of the studied Grts display HREE core patterns that are parallel to or more positively sloping than the HREE patterns of the rims. All of the facts mentioned above are evaluated in the discussion section. Minor and trace element analyses of each Grt, including rim-core-rim profiles, are shown in Table S4. Trace element patterns normalized to the chondritic reservoir (CHUR, [44]) of each Grt are shown in Figure S3.

\subsection{Garnet as a Pressure and Temperature Sensor}

The geothermobarometric calibrations used include anhydrous minerals, and their stability range covers the granulite metamorphic field. The studied samples correspond to basic and intermediate orthogneisses, one acid orthogneiss, and one ultramafic granulite (Tables $2-4$ and S5).

Table 2. Results of Grt-Opx-Pl-Qz geobarometer calibrations from [45-47] with two inputs of T: $800{ }^{\circ} \mathrm{C}$ and $900{ }^{\circ} \mathrm{C}$.

\begin{tabular}{|c|c|c|c|c|c|c|c|}
\hline \multirow{2}{*}{\multicolumn{2}{|c|}{$\begin{array}{c}\text { Sample } \\
\left.\text { T ( }{ }^{\circ} \mathrm{C}\right)\end{array}$}} & \multicolumn{2}{|c|}{$\begin{array}{c}\text { Newton and Perkins (1982) } \\
\text { (GPa) }\end{array}$} & \multicolumn{2}{|c|}{ Bohlen et al. (1983a) (GPa) } & \multicolumn{2}{|c|}{$\begin{array}{l}\text { Perkins and Chipera (1985) } \\
(\mathrm{GPa})\end{array}$} \\
\hline & & \multirow{2}{*}{$\frac{800{ }^{\circ} \mathrm{C}}{0.78}$} & \multirow{2}{*}{$\frac{900{ }^{\circ} \mathrm{C}}{0.82}$} & \multirow{2}{*}{$\frac{800{ }^{\circ} \mathrm{C}}{1.11}$} & \multirow{2}{*}{$\frac{900{ }^{\circ} \mathrm{C}}{1.14}$} & \multirow{2}{*}{$\frac{800{ }^{\circ} \mathrm{C}}{1.09}$} & \multirow{2}{*}{$\frac{900{ }^{\circ} \mathrm{C}}{1.18}$} \\
\hline LCOx59a & Orthogneiss B ${ }^{1}$ & & & & & & \\
\hline $\mathrm{LCO} 559 \mathrm{~b}$ & Orthogneiss B ${ }^{1}$ & 0.80 & 0.85 & 1.13 & 1.26 & 1.12 & 1.22 \\
\hline LCOx61 & Orthogneiss B ${ }^{1}$ & 0.80 & 0.88 & 1.13 & 1.26 & 1.12 & 1.22 \\
\hline LCOx69b & Orthogneiss $\mathrm{A}^{2}$ & 0.83 & 0.91 & 1.08 & 1.21 & 1.17 & 1.23 \\
\hline LCOx107 & Orthogneiss I ${ }^{3}$ & 0.80 & 0.85 & 1.13 & 1.26 & 1.12 & 1.22 \\
\hline
\end{tabular}

${ }^{1}$ B: Basic, ${ }^{2}$ A: Acid, and ${ }^{3}$ I: Intermediate.

Table 3. Results of Grt-Opx geothermometer calibrations from [48-50] with two inputs of P: 0.9 GPa and 1.0 GPa.

\begin{tabular}{|c|c|c|c|c|c|c|c|}
\hline & \multirow{2}{*}{$\begin{array}{l}\text { Sample } \\
\text { P (GPa) }\end{array}$} & \multicolumn{2}{|c|}{$\begin{array}{l}\text { Lee and Ganguly (1988) } \\
\qquad\left({ }^{\circ} \mathrm{C}\right)\end{array}$} & \multicolumn{2}{|c|}{$\begin{array}{c}\text { Bhattacharya et al. (1991) } \\
\left({ }^{\circ} \mathrm{C}\right)\end{array}$} & \multicolumn{2}{|c|}{ Lal (1993) $\left({ }^{\circ} \mathrm{C}\right)$} \\
\hline & & 1.0 & 0.9 & 1.0 & 0.9 & 1.0 & 0.9 \\
\hline \multirow{3}{*}{ LCOx35 } & \multirow{3}{*}{ Ultramafic granulite } & 802 & 896 & 862 & 850 & 790 & 784 \\
\hline & & 896 & 890 & 857 & 846 & 785 & 779 \\
\hline & & 848 & 843 & 815 & 805 & 743 & 738 \\
\hline LCOx59a & Paragneiss Qz-Fsp & 827 & 822 & 792 & 781 & 760 & 754 \\
\hline LCOx59b & Orthogneiss B ${ }^{1}$ & 843 & 838 & 807 & 797 & 768 & 763 \\
\hline $\mathrm{LCOx61}$ & Orthogneiss B ${ }^{1}$ & 784 & 779 & 762 & 752 & 728 & 723 \\
\hline $\mathrm{LCO} \times 69 \mathrm{~b}$ & Orthogneiss $\mathrm{A}^{2}$ & 821 & 816 & 796 & 785 & 765 & 759 \\
\hline LCOx107 & Orthogneiss I ${ }^{3}$ & 866 & 860 & 822 & 811 & 815 & 810 \\
\hline LCOx108 & Orthogneiss B ${ }^{1}$ & 948 & 942 & 893 & 881 & 839 & 833 \\
\hline
\end{tabular}

${ }^{1}$ B: Basic, ${ }^{2}$ A: Acid, and ${ }^{3}$ I: Intermediate. 
Table 4. Results of Grt-Cpx calibrations from [51,52] were used with two inputs of P: 0.9 GPa and $1.0 \mathrm{GPa}$.

\begin{tabular}{cccccc}
\hline & Sample & Ellis and Green $(\mathbf{1 9 7 8})\left({ }^{\circ} \mathbf{C}\right)$ & \multicolumn{2}{c}{ Krogh $^{(1988)}\left({ }^{\circ} \mathbf{C}\right)$} \\
\hline & $\mathbf{P}(\mathrm{GPa})$ & $\mathbf{0 . 9}$ & $\mathbf{1 . 0}$ & $\mathbf{0 . 9}$ & $\mathbf{1 . 0}$ \\
\hline LCOx61 & Orthogneiss B & 756 & 753 & 702 & 698 \\
LCOx69b & Orthogneiss A $^{2}$ & 739 & 738 & 680 & 677 \\
LCOx94a & Orthogneiss B $^{1}$ & 774 & 771 & 718 & 715 \\
LCOx98 & Orthogneiss I $^{3}$ & 762 & 759 & 710 & 707 \\
LCOx107 & Orthogneiss I $^{3}$ & 763 & 760 & 715 & 712 \\
\hline
\end{tabular}

${ }^{1}$ B: Basic, ${ }^{2}$ A: Acid, and ${ }^{3}$ I: Intermediate.

Opx-Pl-Qz geobarometer calibrations of [45-47] have been used. The obtained P with two inputs of $\mathrm{T}\left(800{ }^{\circ} \mathrm{C}\right.$ and $\left.900{ }^{\circ} \mathrm{C}\right)$ display a wide range, from $\sim 0.8$ to $\sim 1.4 \mathrm{GPa}$. Nevertheless, the most common P is between 1.0 and 1.1 GPa (Table 2).

Grt-Opx geothermometer calibrations from [48-50], and Grt-Cpx calibrations from [51] and [52] have been used with two inputs of $\mathrm{P}(0.9 \mathrm{GPa}$ and $1.0 \mathrm{GPa})$. The obtained T using a Grt-Opx geothermometer display a range between approximately $720^{\circ} \mathrm{C}$ and $900{ }^{\circ} \mathrm{C}$ (Table 3), and the obtained $\mathrm{T}$ using Grt-Cpx geothermometer range between approximately $677^{\circ} \mathrm{C}$ and $770{ }^{\circ} \mathrm{C}$ (Table 4).

The P-T diagram, which includes the intersection between the Grt-Opx-Pl-Qz geobarometer and the Grt-Opx geothermometer applied to the same samples, is shown in Figure 8. The most likely P-T conditions for this intersection (yellow color) are $0.8-0.9 \mathrm{GPa}$ and $700-800{ }^{\circ} \mathrm{C}$. Therefore, the obtained stability field—medium granulite facies-is close to the amphibolite facies high-medium field.

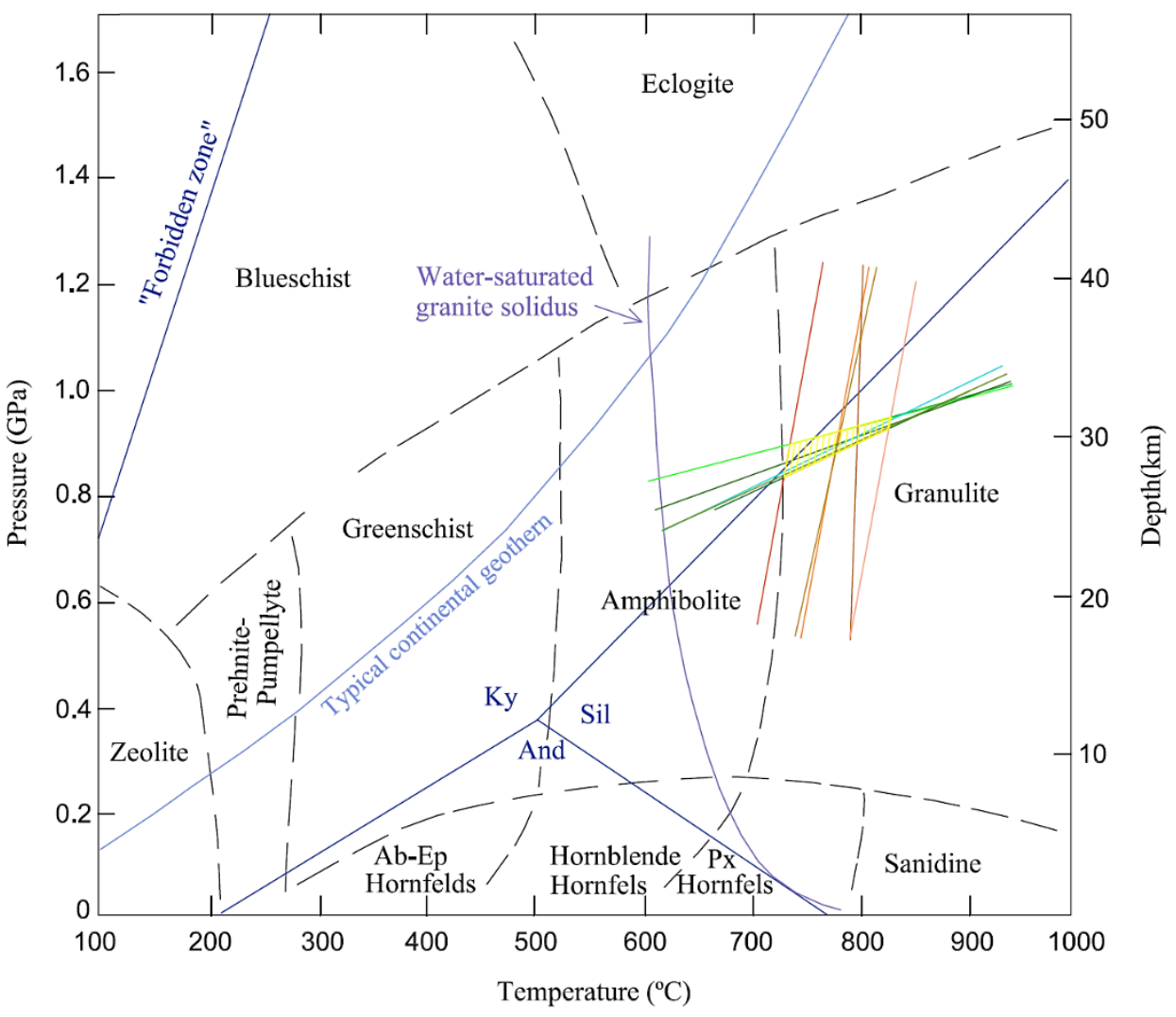

GrtOpxP1Qz_LCOx59a GrtOpxP1Qz_LCOx59b GrtOpxPlQz LCOx61 GrtOpxP1Qz_LCOx69b GrtOpxPlQz_LCOx107

GrtOpx_LCOx59a GrtOpx_LCOx59b GrtOpx_LCOx61 GrtOpx_LCOx69b GrtOpx_LCOx107

Figure 8. P-T diagram including the intersection between the Grt-Opx-Pl-Qz geobarometer data obtained with two inputs of $\mathrm{T}\left(800^{\circ} \mathrm{C}\right.$ and $\left.900^{\circ} \mathrm{C}\right)$ and the two Grt-Opx geothermometer P inputs (0.9 and $\left.1.0 \mathrm{GPa}\right)$ in the same samples. The obtained stability field is marked in a yellow shade. 
Grt-Bi geothermometer calibrations from [53-55] with an input of 0.9 GPa have been used in two orthogneiss samples. The obtained $\mathrm{T}$ displays a range between approximately $609{ }^{\circ} \mathrm{C}$ and $674{ }^{\circ} \mathrm{C}$ (Table S5). The Grt-Bi geothermometer involves Bi as a hydrous mineral, and the obtained $\mathrm{T}$, which is lower than the other geothermometric results, reflects the retrograde stage in the amphibolite facies field.

\section{Discussion}

\subsection{Garnet Petrography}

The studied Grts display two main textural features: (a) subinterstitial or interstitial borders related to the Grt crystal resorption, indicating that the nucleation of these Grts occurred during a stage of prograde metamorphism ([39], Figure 4a,e) and (b) Grts with idiomorphic borders, which are smaller than interstitial Grts (e.g., Figure 4h,n), indicating that these Grts nucleated during a retrograde stage, in which the T reached did not allow the reabsorption of their borders. There are both Grt types, those with reabsorbed borders and smaller Grts with idiomorphic borders, in some of the studied samples. Grts of different grain sizes are likely to form in a polyphase evolution [56]. Therefore, southwestern OC Grt nucleation occurred in the prograde and the retrograde stages, indicating different generations of Grts.

Referring to the relationship between the Grt porphyroblasts and the matrix, it should be noted that in some cases, Grts display ocelli textures and some pressure shadows (e.g., Figure $4 a, d, j)$. However, in any case, textural features that would indicate any rotation have been observed. Backscattered electron images (Figure S1), and major element rim-core-rim profiles (Figure S2) are mostly homogeneous. The HT to ultra-HT (UHT) metamorphism almost or completely erased the prograde textural history of the Grt porphyroblasts [39]. Textural and mineralogical features attributable to the retrograde stage are few and are present in a rather dispersed way (e.g., thin Chl rims Figure 4i). Therefore, an exhumation of the orogen without significant late deformation episodes is deduced. This fact is consistent with the OC evolution [57]. The stability field of the studied Grts is on the HT-(UHT) granulite-facies since the main mineral association comprises anhydrous minerals and, in many cases, high-grade metamorphic hydrated minerals such as pleochroic Amp and Bi (Table 1 and Figure 4d,m).

\subsection{Garnet Geochemistry}

The main Grt end member is Alm (Fe). The high variation in Prp ( $\mathrm{Mg})$ and Grs (Ca) content as the second and third, respectively, the most abundant end members, is related to the nature of the protoliths, e.g., Grts from ultramafic rocks have the highest Prp content, and Grts from amphibolite have the highest Grs content. The Qz-Fsp paragneiss lithotype displays the largest variation range in all of their main components. This fact suggests a wide compositional variation in the protoliths of this lithotype (Table 1). The Grts from the LCOx78, LCOx98, LCOx101, and LCOx107 orthogneiss samples display Grs as a second main end member (Figure $5 \mathrm{~b}$ ). These samples display low $\mathrm{SiO}_{2}$ concentrations: $\mathrm{LCOx} 78=51.3 \% \mathrm{SiO}_{2}, \mathrm{LCO} 98=54.3 \% \mathrm{SiO}_{2}, \mathrm{LCOx} 101=49.2 \% \mathrm{SiO}_{2}, \mathrm{LCOx} 107=52.2 \%$ $\mathrm{SiO}_{2}$ (Table S6). This low $\mathrm{SiO}_{2}$ is consistent with the composition of some high-grade $\mathrm{Al}$ metamorphic Grts from basic (mafic) granulites following [2].

Grts from paraderivate and orthoderivate samples from the southwestern OC can be differentiated (Figure 7) by the minor and trace element patterns normalized to the chondritic reservoir (CHUR, [44]). This is a consequence of the protolith nature and the mineral association of each lithotype. Grts from paraderivate samples are more enriched in $\mathrm{Rb}$, $\mathrm{Ba}, \mathrm{Pb}, \mathrm{Ni}$, and $\mathrm{Zn}$ than those from the orthoderivate samples. WR from the paraderivate samples are enriched in $\mathrm{Rb}$ and $\mathrm{Pb}$ and depleted in $\mathrm{Ni}$ and $\mathrm{Zn}$, with respect to the WR from orthoderivate samples (Table S6). The $\mathrm{Rb}$ and Ba substitute $\mathrm{K}$, and the concentration of $\mathrm{K}_{2} \mathrm{O}$ in the paraderivate WR samples is much higher than in the orthoderivate samples. This fact is consistent with the protolith nature of the orthoderivate samples [58]. Apart from that, the concentrations of $\mathrm{Ni}$ and $\mathrm{Zn}$ are higher in Grts from paraderivate samples than in 
Grts from orthoderivate. This observation indicates that in the orthoderivate samples, the other mineral phases of the rock have a higher affinity for these elements, e.g., Cpx, Amp, and Bi (Table 1). Finally, Grts from the orthoderivate samples are enriched in Ti and V with respect to Grts from the paraderivate samples. This fact also occurs when these elements are looked at in the WR. Ti and V are typically compatible elements in Ilm and Ti-Mag, and an increase in Ti solubility is correlated to the $\mathrm{Ca}$ and $\mathrm{Fe} / \mathrm{Mg}$ ratios in Grt [59].

Broadly, Grts from the paraderivate samples are more enriched in REE than those from the orthoderivate samples (Figure 7). This feature is related to the presence of Opx/Cpx and Amp as main mineral phases in the orthogneiss samples (Table 1), which also fractionate REE [60,61]. It is beyond the scope of this study to conduct an in-depth analysis of the minor and trace elements of the other mineral phases of the studied samples.

Grts from para- and orthoderivate samples display 0.2-1.1 Eu/ $\mathrm{Eu}^{*}$ anomalies (Table S4n,o). This fact indicates that almost all the Grts were formed while Pl was stable [62]. On the other hand, this fact does not rule out the interpretation that some Grts were peritectic [63]. $\mathrm{The} \mathrm{Eu} / \mathrm{Eu}^{*}$ anomalies are higher in Grts from ortho- than paraderivate samples. This fact probably reflects that the Grts from the paraderivate samples have been in contact with partial melts and that the Grts from the orthoderivate samples have been in contact with total melts (e.g., [64]). The presence of migmatites in the G1 group of the study site supports this statement (Figure 3e).

\subsection{Structural Implication for The Oaxacan Complex}

If the REE core and rim profiles of southwestern OC Grts are compared, Grts from LCOx78 and LCOx83b orthogneiss samples display lower La concentrations in their cores with respect to their rims. On the other hand, Grts from the LCOx49 orthogneiss sample has lower Ce and Pr concentrations in their cores with respect to their rims (Figure S3). These three samples are located near regional fractures, which probably mobilized their LREE at the Grt rims (Figure 2). Apart from that, the resorption/(recrystallization) processes during retrogression and Grt growth kinetics generate HREE $+Y$ enrichment at the Grt rims [65-67]. The Grt from the LCOx98 sample accomplishes this feature and, to a lesser extent, so does the Grt from the LCOx49 sample (Figure S3). As the OC is in granulite facies metamorphism, it is more likely that the features of these Grts reflect resorption processes.

A Grt-Opx-Pl-Qz geobarometer includes anhydrous mineral phases and orthopyroxene (which is the index mineral of granulite facies). Thus, the data provided by this geobarometer is close to the metamorphic peak P. In this work, the P data obtained with an input of $900{ }^{\circ} \mathrm{C}$ is considered to be more realistic because the metamorphic peak $\mathrm{T}$ obtained in the P-T equilibrium phase diagram from the southwestern $\mathrm{OC}$ is at $825-875{ }^{\circ} \mathrm{C}$ [25]. On the other hand, Grt-Opx-Pl-Qz geobarometer results are $>1.3 \mathrm{GPa}$ in some calculations (Table 2). According to the metamorphic peak $P$ results obtained from the southwestern OC, 0.8-1.0 GPa [25], these data have been discarded because they are too far from other values. In agreement with [68], the northern OC Grt-Opx-Pl-Qz geobarometer gives $0.75 \pm 0.1 \mathrm{GPa}$ using the calibration from [45] and $0.73 \pm 0.1 \mathrm{GPa}$ using the calibration from [46]. Therefore, the P obtained in the southwestern OC ( 0.8-1.2 GPa) is higher than the P obtained in the northern part.

In some outcrops from the central and southern study sites, the occurrence of Grt with subinterstitial borders becomes very noteworthy in Qz-Fsp paragneiss and intermediate and basic orthogneiss lithotypes, even containing true garnetites in some samples (e.g., Figure $3 b, c, e)$. Consequently, this fact has implications for the southwestern OC P conditions. The copious presence of Grts is also reported in gabbroic mafic orthogneisses from northern OC [27] and the Oaxaquia realm (Novillo Gneiss, [69]). The coexistence of Opx + $\mathrm{Cpx}+\mathrm{Pl}$ in metabasic rocks is a synonym of granulite facies [70]. However, this association is only stable at low and intermediate $\mathrm{P}$. If the $\mathrm{P}$ increases, Opx reacts with $\mathrm{Pl}$ to create Grt, following the reaction $\mathrm{Opx}+\mathrm{Pl}=\mathrm{Grt}+\mathrm{Cpx}+\mathrm{Qz}$ [71]. The Opx destabilization starts at approximately $0.95 \mathrm{GPa}$ in a prograde stage [72,73]. According to the OC exhumation history [57], this reaction only occurs in a prograde stage and not in a retrograde stage since 
the latter implies a decrease in P. Here, the hypothesis that these kinds of Grts report that the P metamorphic peak is chosen, so the Grts are of pre- or syn-Grenvillian orogeny in the prograde stage. There is no case where Grts display mineral rims that report the retrograde stage, assuming that the textural characteristics of the prograde stage have been erased due to the HT-(UHT). These facts can be justified due to the obtained geothermobarometric results, suggesting a metamorphic peak around 1.0-1.1 GPa. Thus, it is very likely that an $\mathrm{Opx}+\mathrm{Pl}=\mathrm{Grt}+\mathrm{Cpx}+\mathrm{Qz}$ [71] reaction occurred in the rocks from southwestern OC.

In the Novillo Gneiss [74], three types of granulites are differentiated according to mineral association: (a) Grt + Opx granulites, (b) Grt + Cpx granulites, and (c) pyroxene granulites. The P metamorphic peak obtained from Grt + Opx granulites in the Novillo Gneiss is $0.89-0.97$ GPa [74]; hence, the metamorphic peak P obtained in this study is consistent with these data. Apart from that, [75] divided the Novillo Canyon orthogneisses into: (1) an older group of K-rich granulites (granitic gneiss) with a mineral association of $\mathrm{Pl}+\mathrm{Cpx}+\mathrm{Opx}+\mathrm{Grt}$ and gabbroic granulites and (2) a relatively younger group of charnockitic gneisses and anorthositic metagabbros, later defined as AMCG series by [69]. Based on the above, it seems that the central and southern Grt-bearing orthogneisses from southwestern OC belong to the series of old gabbros, from which [74] establishes the metamorphic peak conditions on Novillo Gneiss using classical geothermobarometric studies.

Grt-Opx and Grt-Cpx geothermometers include anhydrous mineral phases. A GrtOpx geothermometer includes the index mineral of the granulite facies (Opx), so the $\mathrm{T}$ obtained using this geothermometer $\left(723-896^{\circ} \mathrm{C}\right.$, Table 3$)$ is higher than those obtained in the Grt-Cpx geothermometer $\left(774-702{ }^{\circ} \mathrm{C}\right.$, Table 4$)$. In this work, the T results obtained from Grt-Opx with an input of $1.0 \mathrm{GPa}$ (Figure 9) are in line with the peak T obtained from southwestern OC, $825-875{ }^{\circ} \mathrm{C}$ [25]. On the other hand, T obtained using Grt-Cpx constrains the beginning of the retrograde stage.

A summary of the most important findings related to the geometry of the orogen at the study site is shown in Figure 9. In this figure, the molar ratio of Prp as the main end member, $\mathrm{Mg} / \mathrm{Mg}+\mathrm{Fe}$, and $\mathrm{Ti}$ and $\mathrm{Al}$ in the octahedral site data is represented, together with the Grt-Opx-Pl-Qz geobarometer and obtained Grt-Opx geothermometer results. Higher Prp concentration in Grt implies higher P and a higher $\mathrm{Mg} / \mathrm{Mg}+$ Fe ratio as well as higher $\mathrm{T}$ (e.g., $[3,47,76])$. Note that the trace element composition of Grts does not substantially affect the diffusion coefficients of Fe and $\mathrm{Mg}$ [2]; therefore, Grt trace elements have not been considered in Figure 9. Grts from ultramafic granulite (LCOx35 sample) display the highest $\mathrm{Mg}$ content. Due to the composition of this lithotype, its $\mathrm{Mg}$ content is less related to the metamorphic processes. The same reasoning can be applied to the Grts from the anatectic marble (LCOx73 sample).

Most of the Grts with the highest $\mathrm{Al}$ at the octahedral position are those that the other data point to as having higher P. However, two samples do not fulfill this condition (LCOx78 and LCOx107). Some Grts with the most Ti at the octahedral position are those that the other data point to as having higher T. Nevertheless, as mentioned above, the Ti solubility in Grts from HT-UHT rocks and the granulite facies metamorphism is characterized by high recrystallization rates [77]. If all of these data are plotted together in Figure 9, they define four groups: (1) high P-T sectors, (2) medium P-T sectors (the most common), (3) low $\mathrm{P}-\mathrm{T}$ sectors, and (4) medium $\mathrm{T}$ and low $\mathrm{P}$ sectors. If the same P-T sectors from the central and southern part of the study site are joined together, it can be seen that they define a particular NNW-SSE or NW-SSE trend. To a lesser degree, although this situation also occurs in the NW part of the study site, only some sectors have an equal magnitude of $\mathrm{T}$ or $\mathrm{P}$, but not in both variables. Based on the information above, some outcrops display different P-T conditions in the study site, so they belong to different structural levels of the orogen. 


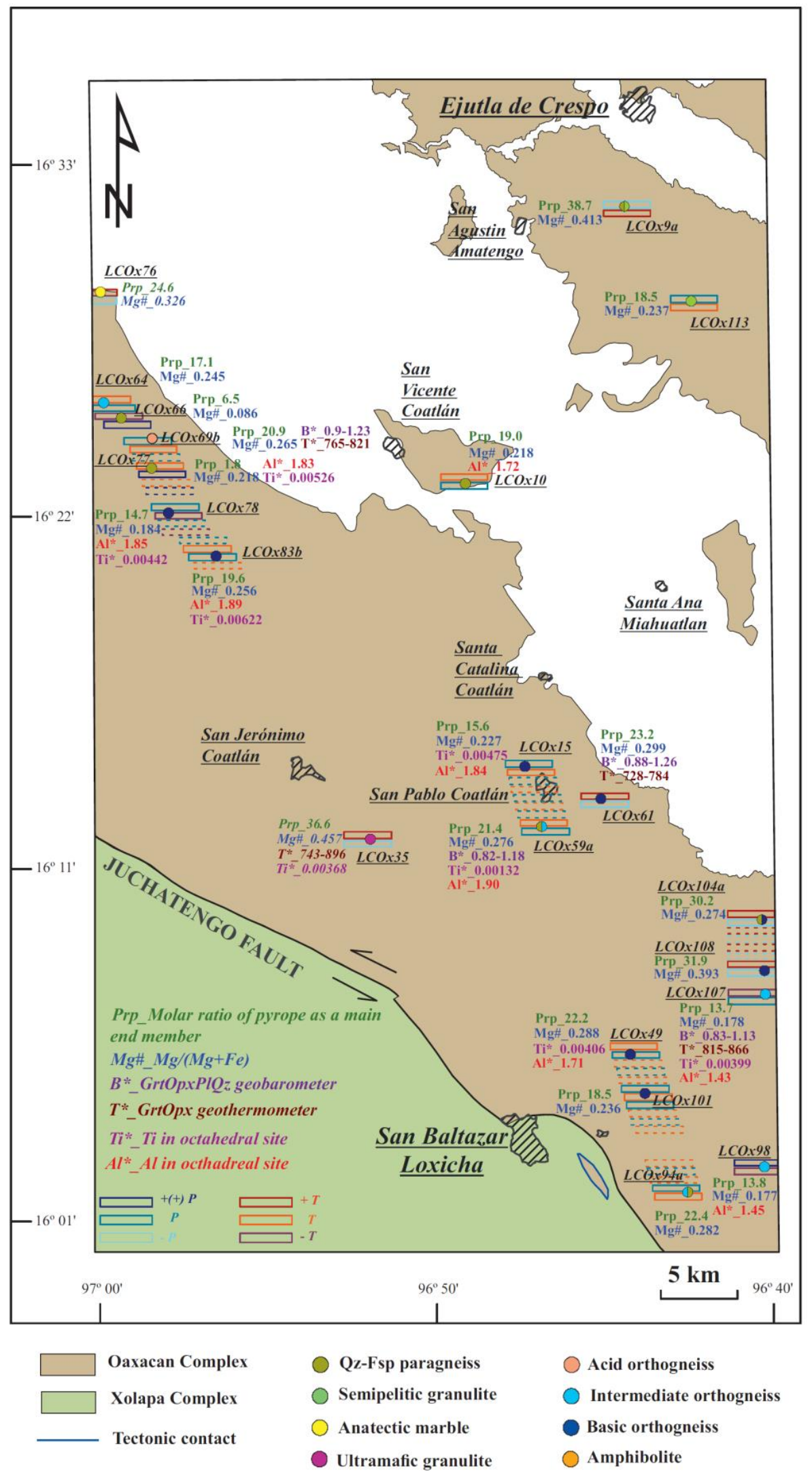

Figure 9. A summary of the most important findings related to the geometry of the orogen in the study site. In this figure, the molar ratio of Prp as the main end member, $\mathrm{Mg} / \mathrm{Mg}+\mathrm{Fe}$, $\mathrm{Ti}$, and $\mathrm{Al}$ in octahedral site data together with the Grt-Opx-Pl-Qz geobarometer and Grt-Opx geothermometer results obtained are represented. 


\section{Conclusions}

Southwestern OC Grts display two main textural features: (a) subinterstitial or interstitial borders related to the late resorption of the Grt crystals nucleated in a prograde metamorphism stage and (b) Grts with idiomorphic borders that are smaller than interstitial Grts that were nucleated in a retrograde stage. As such, in southwestern OC, there are two different generations of Grts nucleated in a polyphase evolution.

HT-(UHT) metamorphism almost or completely erased the prograde textural history of Grt porphyroblasts, and retrograde metamorphism textural features are few and are only present in a rather dispersed way. These facts make it possible to infer an exhumation of the orogen without significant late deformation episodes.

Southwestern OC Grts mainly plot in the granulite field on ternary diagrams based on the Grt main end members Alm, Prp, Grs, and Sps. The general Grt composition of the Qz-Fsp paragneiss lithotype is $\mathrm{Alm}_{41-73} \operatorname{Prp}_{2-42} \mathrm{Grs}_{3-20} \mathrm{Sps}_{1-8}$; for the semipelitic granulite lithotype, it is $\mathrm{Alm}_{58-63} \operatorname{Prp}_{15-20} \mathrm{Grs}_{19-22} \mathrm{Sps}_{2-3}$; for the orthogneiss lithotype, it is Alm ${ }_{48-66} \operatorname{Prp}_{13-33} \mathrm{Grs}_{9-20} \mathrm{Sps}_{2-11}$; for the amphibolite lithotype, it is $\mathrm{Alm}_{49-51} \operatorname{Prp}_{6-7} \mathrm{Grs}_{30-34} \mathrm{Sps}_{10-13}$; for the ultramafic granulite lithotype, it is $\mathrm{Alm}_{43-49} \operatorname{Prp}_{31-37} \mathrm{Grs}_{18-19} \mathrm{Sps}_{2}$; and for the anatectic marble lithotype, it is $\mathrm{Alm}_{64} \operatorname{Prp}_{13-16} \mathrm{Grs}_{18-19} \mathrm{Sps}_{3-4}$.

The enrichment in $\mathrm{Rb}, \mathrm{Ba}, \mathrm{Pb}, \mathrm{Ni}$, and $\mathrm{Zn}$ from paraderivate Grt samples and in $\mathrm{Ti}$ and $\mathrm{V}$ from orthoderivate Grt samples is related to the nature of the protoliths and other mineral phases that fractionate the same minor and trace elements. $\mathrm{Eu} / \mathrm{Eu}^{*}$ anomalies from para- and orthoderivate Grt samples indicate that almost all of the Grts formed while Pl was stable, and it does not rule out the interpretation that some Grts were peritectic. Some Grts display rims enriched in HREE+ $Y$, indicating resorption/(recrystallization) processes related to the retrograde stage.

The P obtained using Grt-Opx-Pl-Qz geobarometer in the southwestern OC ( 0.8-1.2 GPa) is higher than the $\mathrm{P}$ obtained in the northern part $(0.73 \pm 0.1 \mathrm{GPa})$. P obtained from southwestern $\mathrm{OC}$ is consistent with the values obtained in the Grenvillian-age granulites of the Novillo Gneiss from northeastern Mexico: $\mathrm{P}=0.89-0.97 \mathrm{GPa}$. Grt-bearing orthogneisses from the central and southern part of the southwestern OC can be correlated to the series of old gabbros from which [74] establishes the metamorphic peak conditions on the Novillo Gneiss using classical geothermobarometric studies. The metamorphic peak T obtained using Grt-Opx geothermometer in southwestern OC samples is $800-896^{\circ} \mathrm{C}$. The T obtained using the Grt-Cpx geothermometer $\left(774-702{ }^{\circ} \mathrm{C}\right)$ reflects the first step of the retrograde stage. Moreover, the T obtained using the Grt-Bi geothermometer $\left(609-674{ }^{\circ} \mathrm{C}\right)$ reflects the retrograde stage in the amphibolite facies field.

Some Grt samples located at the vicinity of regional fractures display LREE enrichments in their rims with respect to their cores. If the molar ratio of Prp as the main end member; $\mathrm{Mg} / \mathrm{Mg}+\mathrm{Fe}, \mathrm{Ti}$, and $\mathrm{Al}$ at the octahedral site data; and the results obtained from the Grt-Opx-Pl-Qz geobarometer and the Grt-Opx geothermometer are plotted together, it is possible to define four P-T sectors. Furthermore, if the same P-T sectors are joined, they define a specific NNW-SSE or NW-SSE trend. Based on the above, some outcrops in the study site display different P-T features, so they belong to different structural levels of the orogen.

Supplementary Materials: The following are available online at https:/ /www.mdpi.com/article/10 .3390/min11080805/s1. Figure S1: Wavelength-dispersive spectrometry images from studied Grts; Figure S2: Rim-core-rim Grt major element profiles ( $\mathrm{Fe}, \mathrm{Mg}$, $\mathrm{Ca}$ and $\mathrm{Mn}$ in \% moles) from studied Grts: Submitted in xlsx format; Figure S3: Rim-core-rim Grt trace element patterns normalized to the chondritic reservoir; Table S1: Microprobe analyses of the studied Grts; Table S2: End members components from studied Grts; Table S3: The tetrahedral, dodecahedral, and octahedral site assignments from studied Grts; Table S4: Minor and trace element analyses, including rim-core-rim profiles, from studied Grts; Table S5: Grt-Bi geothermometer calibrations; Table S6: X-ray fluorescence WR analyses. 
Author Contributions: The individual contributions for this research article are: Conceptualization, L.C. and J.S.; methodology, L.C. and J.S.; software, L.C.; validation, L.C. and J.S.; formal analysis, L.C., J.S. and J.A.G.O.; investigation, L.C. and J.S.; resources, J.S., M.C. and J.A.G.O.; data curation, L.C.; writing-original draft preparation, L.C.; writing-review and editing, L.C., J.S., M.C. and J.A.G.O.; visualization, L.C., J.S. and M.C.; supervision, J.S.; project administration, J.S.; funding acquisition, J.S., M.C. and J.A.G.O. All authors have read and agreed to the published version of the manuscript.

Funding: This research was funded by CONACYT grant number 240226 and DGAPA-UNAM grant number IN111917.

Data Availability Statement: All the data used in this study can be found in the published manuscript and in the Supplementary Material.

Acknowledgments: We are grateful to the following people: Teresa Pi Puig for her help with funding and analytical assistance; Joan Reche Estrada, Fernando Ortega-Gutiérrez, and Roberto Maldonado Villanueva for their help with the conceptualization of the project; Thomas Boulesteix, Fidel Costa, Xavier Llovet, and Manuel Linares for their analytical assistance; and Marco Antonio Argaez for the field assistance.

Conflicts of Interest: The authors declare no conflict of interest.

\section{References}

1. Baxter, E.F.; Scherer, E.E. Garnet Geochronology: Timekeeper of tectonometamorphic Processes. Elements 2013, 9, 433-438. [CrossRef]

2. Borinsky, S.A.; Hoppe, U.; Chakraborty, S.; Ganguly, J.; Bhowmik, S.K. Multicomponent diffusion in garnets I: General theoretical considerations and experimental data for Fe-Mg systems. Contrib. Mineral. Petrol. 2012, 164, 571-586. [CrossRef]

3. Lavrentiev, M.Y.; Westerenen, W.; Allan, N.L.; Freeman, C.L.; Purton, J.A. Simulation of thermodynamic mixing properties of garnet solid solutions at high temperatures and pressures. Chem. Geol. 2006, 225, 336-346. [CrossRef]

4. Locock, A.J. An Excel spreadsheet to classify chemical analyses of amphibolites following the IMA 2012 recommendations. Comp. Geosc. 2014, 62, 1-11. [CrossRef]

5. Skinner, B.J. Physical properties of end-members of the garnet group. Amer. Mineral. 1956, 41, 428-436.

6. Yavuz, F.; Yildirim, D.K. WinGrt, a Windows program for garnet supergroup minerals. J. Geosci. 2020, 65, 71-95. [CrossRef]

7. Hawthorne, F.C. On the calculation of the relative amounts of end-member constituents for garnet. Canad. Mineral. 2020, 1-8. [CrossRef]

8. Nimis, P.; Grütter, H. Internally consistent geothermometers for garnet peridotites and pyroxenites. Contrib. Mineral. Petrol. 2010, 159, 411-427. [CrossRef]

9. Feisel, Y.; White, R.; Palin, R.; Johnson, T. New constrains on granulite facies metamorphism and melt production in the Lewisian Complex, northwest Scotland. J. Metamorph. Geol. 2017, 36, 799-819. [CrossRef]

10. Pyle, J.; Spear, F. Yttrium zoning in garnet: Coupling of major and accessory phases during metamorphic reactions. Geol. Mat. Res. 1999, 1, 1-49.

11. Moore, S.J.; Carlson, W.D.; Hesse, M.A. Origins of yttrium and rare earth element distribution in metamorphic garnet. J. Metamorph. Geol. 2013, 31, 663-689. [CrossRef]

12. Carlson, W.D. Rates and mechanism of Y, REE, and Cr diffusion in garnet. Amer. Mineral. 2012, 97, 1598-1618. [CrossRef]

13. Dempster, T.J.; La Piazza, J.; Taylor, A.G.; Beaudoin, N.; Chung, P. Chemical and textural equilibration of garnet during amphibole-facies metamorphism: The influence of coupled dissolution-reprecipitation. J. Metamorph. Petrol. 2017, 35, 1111-1130. [CrossRef]

14. Mange, M.A.; Morton, A.C. Geochemistry of heavy Minerals. Develop. Sediment. 2007, 58, 345-391. [CrossRef]

15. Condie, K.C. Episodic continental growth and supercontinents: A mantle avalanche connection? Earth. Planet. Sci. Lett. 1998, 163, 97-108. [CrossRef]

16. Hoffman, P.F. Did the Breakout of Laurentia Turn Gondwanaland Inside-Out? Science 1991, 252, 1409-1412. [CrossRef]

17. Ortega-Gutiérrez, F.; Ruiz, J.; Centeno-García, E. Oaxaquia, a Proterozoic microcontinent accreted to North America during the late Paleozoic. Geology 1995, 23, 1127-1130. [CrossRef]

18. Ortega-Gutiérrez, F. El Gneis Novillo y rocas metamórficas asociadas en los Cañones del Novillo y de la Peregrina, Ciudad Victoria, Taumalipas. Rev. Inst. Geol. UNAM 1978, 2, 19-30.

19. Lawlor, P.J.; Ortega-Gutiérrez, F.; Cameron, K.L.; Ochoa-Camarillo, H.; Lopez, R.; Sampson, D.E. U-Pb geochronology, and provenance of the Grenvillian Huiznopala Gneiss of Eastern Mexico. Precam. Res. 1999, 94, 73-99. [CrossRef]

20. Solari, L.A.; Keppie, J.D.; Ortega-Gutiérrez, F.; Cameron, K.L.; Lopez, R.; Hames, W.E. 990 and 1100 Ma Grenvillian tectonothermal events in the northern Oaxacan Complex, southern Mexico: Roots of an orogeny. Tectonophysics 2003, 365, 257-282. [CrossRef]

21. Weber, B.; Hecht, L. Petrology and geochemistry of metaigneous rocks from a Grenvillian basement fragment in the Maya Block: The Guichicovi complex, Oaxaca, southern Mexico. Precambr. Res. 2003, 124, 41-47. [CrossRef] 
22. Weber, B.; González-Guzmán, R.; Majarrez-Juárez, R.; Cisneros de León, A.; Martens, U.; Solari, L.; Hecht, L.; Valencia, V. Late Mesoproterozoic of Early Paleozoic history of metamorphic basement from the southeastern Chiapas Massif Complex, Mexico, and implications for the evolution of NW Gondwana. Lithos 2018, 300-301, 177-199. [CrossRef]

23. Ramírez-Salazar, A. Petrogénesis de las granulitas del Complejo Oaxaqueño. Bachelor's Thesis, Área Nochistlán-Telixtlahuaca. UNAM, Mexico City, Mexico, 2015; p. 83.

24. Schulze, C.; Schaaf, P.; Weber, B. The origin of Pluma Hidalgo Anorthosites, southern Oaxaca, Mexico. In Proceedings of the 10th South American Symposium on Isotope Geology (SSAGI), Puerto Vallarta, Mexico, 22-25 May 2016; p. 160.

25. Culí, L.; Reche-Estrada, J.; Solé, J. Phase equilibria thermobarometry of Grenvillian granulites from the Oaxacan Complex (Mexico): Poster. Goldschmidt 2019, 701. [CrossRef]

26. Whitney, D.L.; Evans, B.W. Abbreviations for names of rock-forming minerals. Amer. Mineral. 2010, 95, 185-187. [CrossRef]

27. Keppie, J.D.; Dostal, J.; Cameron, K.L.; Solari, L.A.; Ortega-Gutiérrez, F.; Lopez, R. Geochronology and geochemistry of Grenvillian igneous suites in the northern Oaxacan Complex, southern Mexico: Tectonic implications. Precambr. Res. 2003, 120, 365-389. [CrossRef]

28. Schulze, C. Petrología y Geoquímica de las Rocas del área de Pluma Hidalgo, Oaxaca e Implicaciones Tectónicas Para el Proterozoico de Oaxaquia. Ph.D. Thesis, UNAM, Mexico City, Mexico, 2011; 369p.

29. Mesino-Hernández, J.C. Microanálisis de Elementos Mayores y Traza en Granate por LA-ICP-MS y su uso Como Trazador de Procedencia en Rocas Sedimentarias Detríticas. Bachelor's Thesis, UNAM, Mexico City, Mexico, 2019; 125p.

30. Keppie, J.D.; Dostal, J.; Miller, B.V.; Ramos-Arias, M.A.; Morales-Gámez, M.; Nance, R.D.; Murphy, J.B.; Ortega-Rivera, A.; Lee, J.W.K.; Housh, T.; et al. Ordovician-earliest Silurian rift tholeiites in the Acatlán Complex, southern Mexico: Evidence of rifting on the southern margin of the Rheic Ocean. Tectonophysics 2008, 461, 130-156. [CrossRef]

31. Culí, L.; Solé., J.; Ortega-Gutiérrez., F. Metamorphic evolution of Proterozoic ultramafic rocks from the Oaxacan Complex (Oaxaca State, southern Mexico): Tectonic implications, Ch. 5. In Southern and Central Mexico: Basement Framework, Tectonic Evolution, and Provenance of Mesozoic-Cenozoic Basins; Martens, U., Molina, R., Eds.; GSA Special Paper; 3300 Penrose Place: Boulder, CO, USA, 2020; Volume 546, 42p. [CrossRef]

32. Culí, L. Petrología, Geoquímica, Termobarometría, Pseudosecciones Metamórficas y Geocronología de la Porción Centro-sur del Complejo Oaxaqueño Oaxaca, México. Ph.D. Thesis, UNAM, Mexico City, Mexico, 2020; 205p.

33. Fitz-Bravo, C.; Castillo-Reynoso, J.E. Carta Geológico-Minera. Ejutla de Crespo E14D67 (Oaxaca), scale 1:50,000; Servicio Geológico Mexicano: Pachuca, México, 2017.

34. Uribe-Luna, J.; Pérez-Reynoso, X. Carta Geológico-Minera. San Baltazar Loxicha E14D87 (Oaxaca), scale 1:50,000; Servicio Geológico Mexicano, Pachuca: Hidalgo, México, 2012.

35. Servicio Geológico Mexicano. Carta Geológico-minera. Zaachila E1412 (Oaxaca), scale 1:250,000; Servicio Geológico Mexicano, Pachuca: Hidalgo, Mexico, 2000.

36. Woodhead, J.; Hellstrom, J.; Hergt, J.; Greig, A.; Maas, R. Isotopic and elemental imaging of geological materials by laser ablation Inductively Coupled Plasma mass spectrometry. Geostand. Geoanal. Res. 2007, 31, 331-343. [CrossRef]

37. Paton, C.; Hellstrom, J.; Paul, B.; Woodhead, J.; Hergt, J. Iolite: Freeware for the visualization and processing of mass spectrometric data. J. Anal. At. Spectrom. 2011, 26, 2508-2518. [CrossRef]

38. Jochum, K.P.; Nohl, U.; Herwig, K.; Lamme, E.; Stoll, B.; Hofmann, A.W. GeoReM: A new geochemical database for reference materials and isotopic standards. Geostand. Geoanal. Res. 2005, 29, 333-338. [CrossRef]

39. Florence, F.P.; Spear, F. Influences of reaction history and chemical diffusion on P-T calculations for staurolite schist from the Littleton Formation, northwestern New Hampshire. Amer. Mineral. 1993, 78, 345-359.

40. Baxter, E.F.; Caddick, M.L.; Dragovic, B. Garnet: A Rock-Forming Mineral Petrochronometer. Rev. Mineral. Geochem. 2017, 83, 469-533. [CrossRef]

41. Spear, F.S. Metamorphic Phase Equilibria and Pressure-Temperature-Time Paths; Mineralogical Society of America Monograph Series; Mineralogical Society of America: Washington, DC, USA, 1993. [CrossRef]

42. Kohn, M.J.; Spear, F. Retrograde net transfer reaction insurance for pressure-temperature estimates. Geology 2000, 28, 1127-1130. [CrossRef]

43. Suggate, S.M.; Hall, R. Using detrital garnet composition to determine provenance: A new compositional database and procedure. Geol. Soc. Lond. Spec. Publ. 2013, 386, 373-393. [CrossRef]

44. Sun, S.S.; McDonough, W.F. Chemical and isotopic systematics of ocean basalts. Implications for mantle compositions and processes. In Magmatism in Ocean Basins; Saunders, A.D., Norry, M.J., Eds.; Geological Society, Special Publications: London, UK, 1989; Volume 42, pp. 313-345. [CrossRef]

45. Newtron, R.C.; Perkins, I. Thermodynamic calibration of geobarometers based on the assemblages garnet-plagioclaseorthopyroxene (clinopyroxene)-quartz. Amer. Mineral. 1982, 67, 203-222.

46. Bohlen, S.R.; Wall, V.J.; Boettcher, A.L. Experimental investigations and application of garnet granulite equilibria. Contrib. Mineral. Petrol. 1983, 83, 52-61. [CrossRef]

47. Perkins, D.; Chipera, S. Garnet-orthopyroxene-plagioclase-quartz barometry: Refinement and application to the English River subprovince and the Minnesota River valley. Contrib. Mineral. Petrol. 1985, 89, 69-80. [CrossRef] 
48. Lee, H.Y.; Ganguly, J. Equilibrium compositions of coexisting garnet and orthopyroxene: Experimental determinations in the system $\mathrm{FeO}-\mathrm{MgO}-\mathrm{Al}_{2} \mathrm{O}_{3}-\mathrm{SiO}_{2}$, an application. J. Petrol. 1988, 29, 93-113. [CrossRef]

49. Bhattacharaya, A.; Mohanty, I.; Maji, A.; Sen, S.K.; Raith, M. Non-ideal mixing in the phlogopite-annite binary: Constraints from experimental data on $\mathrm{Mg}$-Fe partitioning and reformulation of the biotite-garnet geothermometer. Contrib. Mineral. Petrol. 1991, 111, 87-93. [CrossRef]

50. Lal, R.K. Internally consistent recalibrations of mineral equilibria for geothermobarometry involving garnet-orthopyroxeneplagioclase-quartz assemblage and their application to the South Indian granulites. J. Metamorph. Geol. 1993, 11, 855-866. [CrossRef]

51. Ellis, D.J.; Green, D.H. An experimental study of the effect of Ca upon garnet-clinopyroxene Fe-Mg Exchange equilibria. Contrib. Mineral. Petrol. 1978, 71, 13-22. [CrossRef]

52. Krogh, E.J. The garnet-clinopyroxene Fe-Mg geothermometer, a reinterpretation of existing experimental data. Contrib. Mineral. Petrol. 1998, 99, 44-48. [CrossRef]

53. Ferry, J.M.; Spear, F.S. Experimental calibration of the partitioning of Fe and Mg between biotite and garnet. Contrib. Mineral. Petrol. 1978, 66, 113-4117. [CrossRef]

54. Perchuk, L.L.; Lavrent'eva, I.V. Experimental Investigation of Exchange Equilibria in the System Cordierite-Garnet-Biotite; Saxena, S.K., Ed.; Kinetics and Equilibrium in Mineral Reactions; Springer Inc.: New York, NY, USA, 1983; Chapter 7.

55. Indares, A.; Martignole, J. Biotite-garnet geothermometry in the granulite facies: The influence of Ti and $\mathrm{Al}$ in biotite. Amer. Mineral. 1985, 7, 272-278.

56. Herman, R.; Rubatto, D. Relating zircon and monazite domains to garnet growth zones: Age and duration of granulite facies metamorphism in the Val Malenco lower crust. J. Metamorph. Petrol. 2003, 21, 833-852. [CrossRef]

57. Keppie, J.D.; Ortega-Gutiérrez, F. 1.3-0.9 Ga Oaxaquia (Mexico): Remnant of an arc/backarc on the northern margin of Amazonia. J. S. Am. Earth Sci. 2010, 29, 21-27. [CrossRef]

58. Le Roux, V.L.; Dasgupta, R.; Lee, C.T.A. Mineralogical heterogeneities in the Earth's mantle: Constraints from Mn, Co, Ni and Zn partitioning during partial melting. Earth Planet Sci. Lett. 2011, 307, 395-408. [CrossRef]

59. Ackerson, M.R.; Watson, E.R.; Tailby, N.D.; Spear, F. Experimental investigation into the subduction mechanisms and solubility of Ti in garnet. Amer. Mineral. 2017, 102, 158-172. [CrossRef]

60. Charoy, N.; Raimbault, N. Zr-, Th-, and REE-Rich Biotite Differentiates in the A-type Granite Pluton of Suzhou (Eastern China): The key Role of Fluorine. J. Petrol. 1994, 35, 919-962. [CrossRef]

61. Fornelli, A.; Langone, A.; Micheletti, F.; Piccarreta, G. REE partition among zircon, orthopyroxene, amphibole, and garnet in a high-grade metabasic system. Gond. Rese 2017, 155, 1705-1726. [CrossRef]

62. Clarke, G.L.; Daczko, N.R.; Miescher, D. Identifying relic igneous garnet and clinopyroxene in eclogite and granulite, Breaksea orthogneiss, New Zealand. J. Petrol. 2013, 54, 1921-1938. [CrossRef]

63. Sajeev, K.; Jeong, J.; Kwon, S.; Kee, W.S.; Kim, S.W.; Komiya, T.; Itaya, T.; Jung, H.S.; Park, Y. High P-T granulite relicts from the Imjingang belt, South Korea: Tectonic significance. Gondwana Res. 2010, 17, 75-86. [CrossRef]

64. Irber, W. The lanthanide tetrad effect and its correlation with $\mathrm{K} / \mathrm{Rb}, \mathrm{Eu} / \mathrm{Eu}^{*}, \mathrm{Sr} / \mathrm{Eu}, \mathrm{Y} / \mathrm{Ho}$, and $\mathrm{Zr} / \mathrm{Hf}$ of evolving peraluminous granite suites. Geochim. Cosmochim. Acta 1999, 63, 489-508. [CrossRef]

65. Lanzirotti, A. Yttrium zoning in metamorphic garnets. Geochim. Cosmochim. Acta 1995, 59, 4105-4110. [CrossRef]

66. Hickmott, D.; Spear, F. Major and trace element zoning in garnets from calcareous pelites in the NW Shelburne Falls Quadrangle, Massachusetts: Garnet growth histories in retrograde rocks. J. Petrol. 1992, 33, 965-1005. [CrossRef]

67. Yang, P.; Rivers, T. The origin of Mn and Y annuli in garnet and the thermal dependence of $\mathrm{P}$ in garnet and $\mathrm{Y}$ in apatite in calc-pelite and pelite, Gagnon terrane, western Labrador. Amer. Mineral. 2002, 88, 8-9.

68. Mora, C.; Valley, J.W.; Ortega-Gutiérrez, F. The temperature and pressure conditions of Grenville-age granulite-facies metamorphism of the Oaxacan Complex: Southern Mex. UNAM, Mexico City, Mexico. Rev. Inst. Geol. 1986, 6, $222-242$.

69. Cameron, K.L.; Lopez, R.; Ortega-Gutiérrez, F.; Solari, L.; Keppie, J.D.; Schulze, C. U-Pb geochronology and Pb-isotope compositions of leached feldspars: Constraints on the origin and evolution of Grenville rocks from eastern and southern Mexico. In Proterozoic Tectonic Evolution of the Grenville Orogen in North America; Tollo, R.P., Carriveau, L., McLelland, J.B., Bartholomew, M.J., Eds.; Geological Society of America Special Paper: Boulder, CO, USA, 2004; pp. 755-769.

70. Fettes, D.; Desmons, J. (Eds.) Metamorphic Rocks. A Classification and Glossary of Terms; Cambridge University Press: Cambridge, UK, 2007; 244p.

71. Pattison, D.R.M.; Chacko, T.; Farquhar, J.; McFarlane, C.R.M. Temperatures of Granulite-facies Metamorphism: Constraints from Experimental Phase Equilibria and Thermobarometry Corrected for Retrograde Exchange. J. Petrol. 2003, 44, 867-900. [CrossRef]

72. O'Brien, P.J.; Rötzler, J. High-pressure granulites: Formation, recovery of peak conditions and implications for tectonics. J. Metamorph. Geol. 2003, 21, 3-20. [CrossRef]

73. Brown, M. Crustal melting and melt extraction, ascent and emplacement in orogens: Mechanisms and consequences. J. Geol. Soc. 2007, 164, 709-730. [CrossRef]

74. Orozco-Esquivel, M.T. Geotermobarometría de granulitas precámbricas del basamento de la Sierra Madre Oriental. In Convención Sobre la Evolución Geológica de México; UNAM: Mexico City, Mexico, 1991; pp. 138-140. 
75. Trainor, R.J.; Nance, R.D.; Keppie, J.D. Tectonothermal history of the Mesoproterozoic Novillo Gneiss of eastern Mexico: Support for a coherent Oaxaquia microcontinent. Rev. Mex. Cienc. Geol. 2011, 28, 580-592.

76. Ganguly, J.; Cheng, W.; Chakraborty, S. Cation diffusion in aluminosilicate garnets: Experimental determination in pyropealmandine diffusion couples. Contrib. Mineral. Petrol. 1998, 131, 171-180. [CrossRef]

77. Frost, B.R.; Chacko, T. The granulites uncertainty principle: Limitations on thermobarometry in granulites. J. Geol. 1989, 97, 435-450. [CrossRef] 